\title{
4
}

\section{Remaking Muddy Blue Spaces: Histories of Human-Wetlands Interactions in the Waipā River and the Creation of Environmental Injustices}

There are a diversity of wetlands within Aotearoa New Zealand and a variety of ways of classifying them. Throughout the nineteenth and early twentieth centuries, Europeans used the term "swamp" to refer to all Aotearoa's wetlands. However, technically the term swamp relates only to an area consisting of pooled water and some vegetation cover (Park 2002). Wetlands, from a western scientific perspective, are now broadly defined as "lands transitional between terrestrial and aquatic systems where an oversupply of water for all or part of the year results in distinct wetland communities" (Ausseil et al. 2015; Clarkson et al. 2013, p. 193). Scientists classify wetlands in different ways, including freshwater areas with emergent plants (palustrine), saltwater estuaries and lagoons (estuarine), and freshwater lakes (lacustrine); as well as coastal, interior and riverine; and swamps, bogs, and mires (Clarkson et al. 2013; Parsons 2019). Mātauranga Māori (Māori knowledge) classifies wetlands using different terms, including roto (lake) and moana (lacustrine), poharu (palustrine), manga (creek) and awa (riverine), and muriwai, wahapū and hāpua (estuarine). All the main types of wetlands are found in Aotearoa, in this chapter, we adopt the terms wetlands and repo (wetlands) to refer to the 
diversity of wetland types within the Waipā catchment (Denyer and Robertson 2016; Phillips et al. 2002).

For many commentators, this loss of wetlands is simply a footnote in the broader story of colonial settlement and modernising development; an inevitable consequence of economic and social progress that all societies undertook. Yet Aotearoa's figures are amongst the greatest extent of wetland reduction in the developed world (Clarkson et al. 2013; Park 2001). Less than 10 per cent of its original (pre-human) wetlands remain (as of 2015 figures), with 16 per cent of wetlands retained in the South Island, while less than five per cent remains in the North Island (Ausseil et al. 2015; Clarkson et al. 2013). In the Waikato region, only 8.9 per cent of the wetlands remain (see Figs. 4.1 and 4.2). In comparison, since European colonisation commenced, wetland loss in other settler-colonial states range from a 50 per cent loss in Australia to 53 per cent in the United States of America, and between 65 to 80 per cent in Canada (Davidson 2014; Denyer and Robertson 2016; Mitsch and Gosselink 2000; Park 2002; Parsons 2019). During the same period, the wetlands of European nations were likewise being reduced. France recorded a small reduction (10 per cent reduction). Whereas Netherlands (famous for its extensively re-engineered waterways and dykes) and Britain (where drainage works began in East Anglia from the sixteenth century) both registered a decrease of 60 per cent. In comparison, since European colonisation, the United States has lost 53 per cent of its wetlands, Canada between 65-80 per cent, and Australia 50 per cent (Davidson 2014; Denyer and Robertson 2016; Mitsch and Gosselink 2000; Park 2002). Thus, while many countries drained wetlands and converted them to grasslands and urban areas, the amount and speed of wetland loss in Aotearoa were particularly pronounced in the nineteenth and twentieth century.

In the present-day, increased concerns are being raised about that the state of rivers, including issues of pollution, degradation, and water scarcity, yet wetlands seldom feature in discussions of river health (Azarnivand et al. 2017; Chetty and Pillay 2019; Flint et al. 2017; Hemming et al. 2017; Kansal 2018; O’Donnell and Macpherson 2019). Indeed, a wealth of scholarship examines the plethora of freshwater issues (including river management, drinking water, water allocation) facing Indigenous 


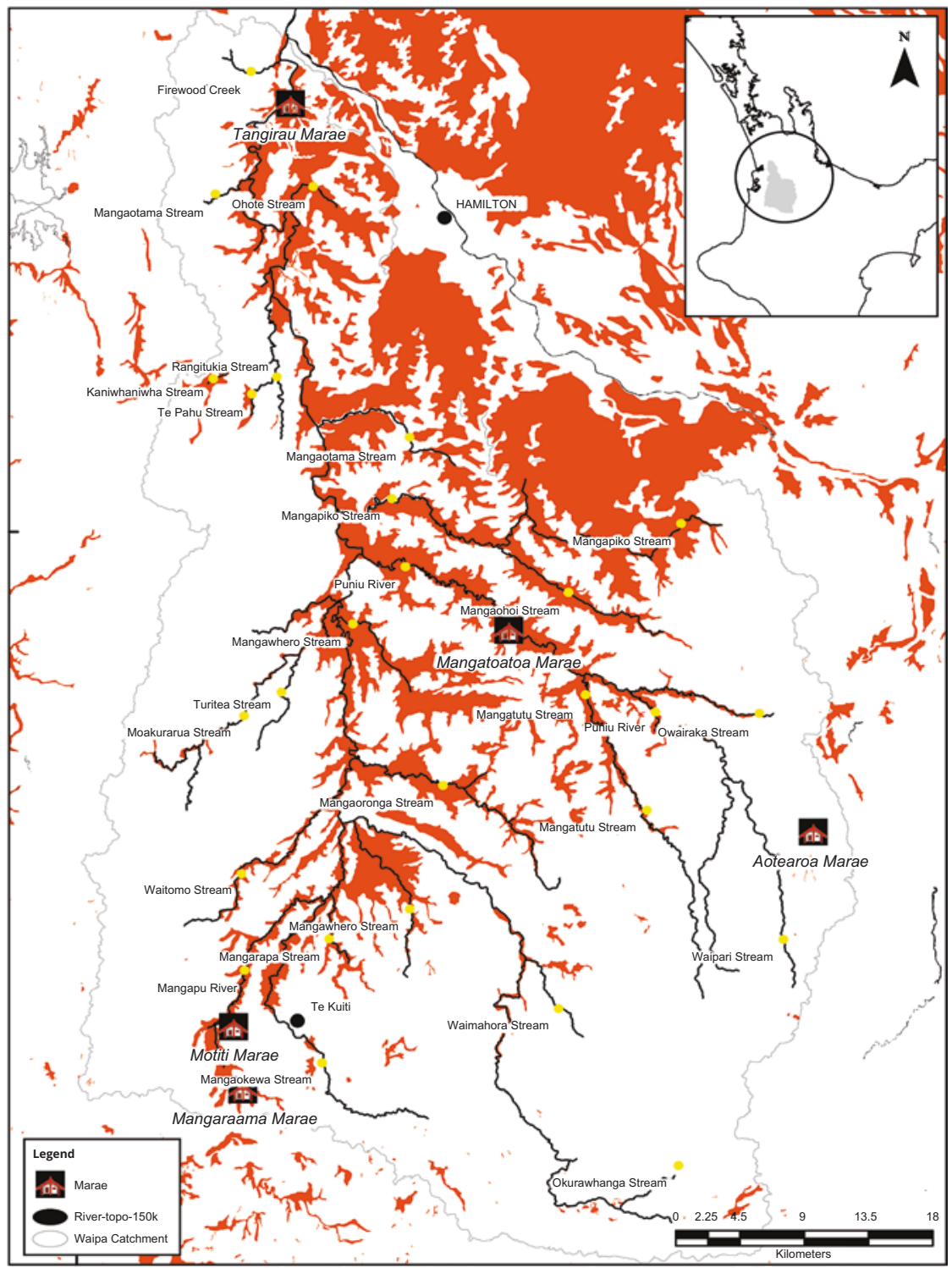

Fig. 4.1 Map of pre-human wetlands in the Waipā catchment 


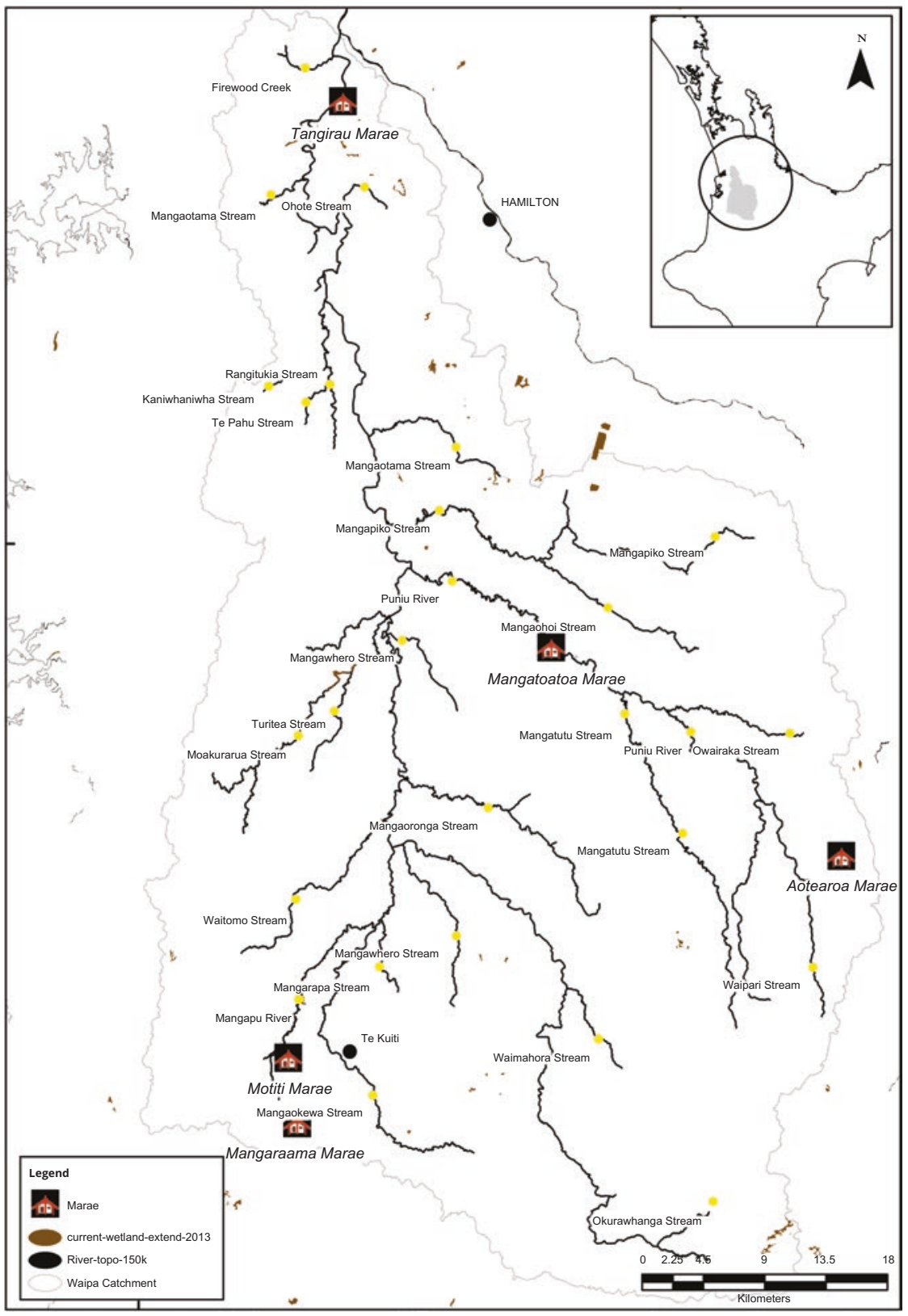

Fig. 4.2 Map of wetlands in Waipā catchment in 2016 
peoples; however, wetlands receive only cursory mention (Bradford et al. 2016; Durette et al. 2009; Hanrahan 2003; Hemming et al. 2017; S. Jackson 2018; Morris and Ruru 2010; Patrick 2011; Poelina et al. 2019). The lack of explicit focus on wetlands is reflective, we suggest, of the privileging of settler-colonial histories, knowledge, values, and ways of conceptualising freshwater geographies. In this chapter, we document how the physical and discursive removal of wetlands, from waterscapes and landscapes, were manifestations of settler-colonial domination. We suggest the need to re-focus (decolonise) freshwater histories to encompass wetlands as an integrated and essential part of historical (and future) healthy and productive waterscapes and landscapes. Accordingly, in this chapter, we challenge the collective amnesia about wetlands in accounts of academic and practitioner dialogue about river health and management and through a historical case study demonstrate how wetland reduction (erasure) was a constitutive part of the mechanisms of settlercolonial domination. We argue that wetland loss was (and is still) an environmental injustice that had specific implications for Indigenous peoples due to their material, socio-cultural, and spiritual connections.

The incremental actions taken by individuals and institutions over decades beginning with the invasion of the Waikato in 1863 and continuing into the first three decades of the twentieth century amounted to ecological transformations of Māori waterscapes (outlined in Chap. 3). Colonialism and capitalist exploitation were tightly bound together, with Māori livelihoods, natural resource management and land-tenure arrangements, and governance structures all radically disrupted by the introduction of new materials, biota, technologies, peoples, policies and institutional structures (Whyte 2018, p. 135). By seeking to establish ongoing environmental injustices for Māori communities (distributive, procedural, recognitional, and cosmological injustices). We focus on the context of settler colonialism within Aotearoa New Zealand and how wetland drainage works strategically undermined Māori resilience, which encompassed the health and wellbeing of Mãori communities as well as their more-than-human relatives (including their rivers, wetlands, lakes, and biota). Countless relationships that link settler colonialism, environmental injustice, and wetland drainage (as acts of environmental violence). In the previous chapter, we explored how Māori principles of 
mauri (life force) and whakapapa (genealogy) were essential parts of how Māori conceptualised and interacted with their waterscapes and constitutive elements of Māori collective continuance across generations of occupation. In this chapter, we examine the disruption and destruction wrought by settler colonialism on Māori communities and waterscapes within the Waipā. One avenue by which settler-colonial violence committed environmental injustice against Māori communities was by strategically weakening Māori health and wellbeing and their collective continuance through the destruction of Māori relationships with their awa (rivers) and repo. At least two forms of environmental injustices (misrecognition and procedural) were a product of settler colonialism and the eco-violence that occurred as a consequence of colonisation. In particular, we highlight how specific government policies, decisions of the courts, and government departments and settler society's failure to recognise Māori relationships with, values attached to, and rights to use and practice rangatiratanga over wetlands, waterways, and lands (supposed guaranteed to Māori under Article Two of the Treaty of Waitangi) formed the basis of cumulative and ongoing environmental injustices.

The structure of the chapter is as follows; we first provide a brief of historical events that coincided with and in some instances directly feed into settler-led operations to drain the wetlands. Next, we explore white (Pākehā) settlers' perceptions of the wetlands of the Waipā River and neighbouring river systems as hazardous and unhealthy spaces. We locate settler conceptualisations of wetlands as hazards as part of broader settlercolonial narratives about what was considered socially, economically, and morally acceptable waterscapes and landscapes for settlers to live and work in (as opposed to Indigenous and non-Indigenous non-white peoples). We then move onto discussing the strategies that were employed to reduce and replace wetlands by the settler state as well as individual settlers; this includes the extensive use of poorly paid non-white workers (both Māori and non-Māori non-Pākehā) who undertook the physical labour of draining the wetlands. Lastly, we highlight how Māori communities (as individuals and members of whānau, hapū and iwi) sought to challenge settler-colonial domination through spontaneous protests, legal cases, and political negotiations to conserve wetlands. 


\section{Settler Imaginative Geographies of the Waipā: 1850s-1860s}

In the decade before the invasion of the Waikato, colonial officials and settlers repeatedly proclaimed their desires to acquire the whole Waikato and Waipā River floodplains for Pākehā settlement; this aim conflict with the aims of the Kingitanga movement (the King movement) and individual iwi to retain their rangatiratanga (authority) over their whenua (land) and retain their mode of life centred on their tikanga (laws) and mātauranga Māori (Māori knowledge). Indeed, settler imaginative geographies of the Waikato discursively dislodged the presence of Māori and their repo in the district even before the actions of the armed forces. Throughout the 1850 s and early 1860s, colonial media and government officials' writings depicted the environs south of the growing Pākehā township of Auckland as a wild and fertile landscape, home to the rapidly depopulating and soon to be erased native population. The Waikato delta was, one journalist reported in 1859, dotted with the "remains of Māori villages" in a state of "fast hastening ... decay", which imparted an "air of picturesque and rustic beauty" to the landscape that was in desperate need to Pākehā settlement (Unknown Author 1859). The Waikato region was imagined by Pākehā commentators to be lying in a state of unuse awaiting the "Anglo-Saxon race" to transform it into a thriving and prosperous region, despite the operations of extensive Māori horticultural operations.

A central part of the settler-colonial project involved the discursive erasure of Māori agricultural success and economic development in the Waikato before and after the 1863 invasion. With the coming of the Pākehā, Māori hapū and iwi within the Waikato and Waipā catchment quickly embraced new knowledges, technologies, plants and animals (Unknown Author 1846) and by the 1840s iwi and hapū were growing diverse cultivations, which included kumara, potatoes, taro, corn, wheat, peaches and apples, as well as other goods (flax and timber) for their use as well as to exchange and trade with other groups (see Fig. 4.3: Illustration of peach orchards along the Waipā River) (Unknown Author 1859, 1864b). In addition to food, hapū (sub-tribes) along the Waipā and 


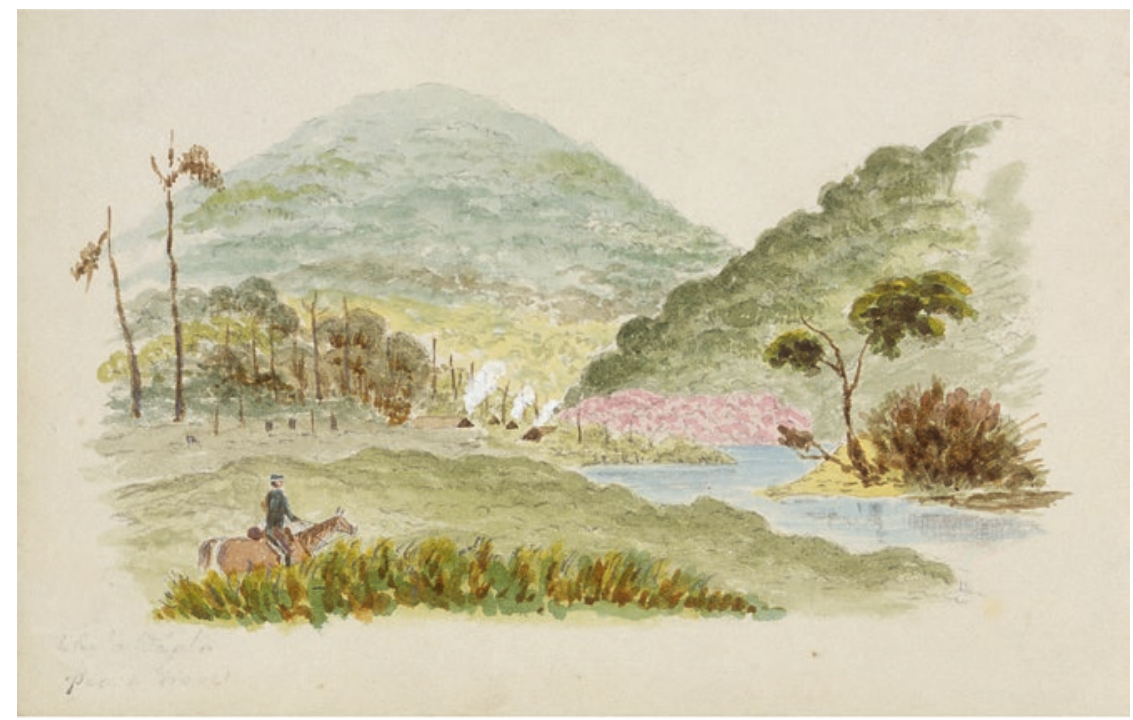

Fig. 4.3 The drawing shows houses at the village of Whatawhata on the banks of the Waipā River (located 12 kilometres west of the present-day city of Hamilton). On the left of the drawing, several houses are visibly located in front of peach trees in blossom. Figures are shown descending the hill, and a Māori man is in a waka (canoe) is going across the river. British soldier Joseph Osbertus Hamley made the drawing in 1864 (many of which were copied from his superior officer) during the British military invasion of the Waikato. (Source: Ref: E-047-q-013. Alexander Turnbull Library, Wellington, New Zealand)

Waikato rivers operated 50 flour mills, with individual hapū constructing their mills to grind their wheat into flour that was exported to settlers living in rapidly expanding urban areas in Aotearoa (Auckland, New Plymouth, Wellington) and Australia (Sydney and Melbourne) (Grey 1849; Hursthouse 1861; Morgan 1849; Unknown Author 1854, 1859). As a consequence of the success of Māori agricultural and economic activities in the 1840s and 1850s, Pākehā journalists dub the WaikatoWaipā Delta "the Garden of New Zealand" (Unknown Author 1854) and the "Granary of North Island" (Hargreaves 1961, p. 72). Yet, rather than acknowledge Māori agricultural operations of Waikato Riverine Māori as evidence of Māori skills as farmers, settler-colonial government officials, travel writers, and journalists chose to ascribe agricultural 
development to the region's fertile soils and good climatic conditions (R. P. Hargreaves 1959; Hargreaves 1961).

By the 1850s settler-colonial discourse narrated that Māori communities living within the Waipā River catchment (and elsewhere) were making poor use of their lands. As one settler journalist wrote regarding the Waikato:

We have been accused at home 'of coveting Naboth's vineyard,' when we have looked with [a] wistful eye on the extensive plains and rich alluvial flats retained by the natives, which they have never cultivated nor ever will! Surely there is no analogy! Naboth's vineyard ${ }^{1}$ was cultivated, or it would not have been a vineyard at all; and I deny that any right-minded man covets the miserably cultivated clearings of the natives. (Unknown Author 1863)

Such narratives-that Māori did not make productive use of their lands and was doomed to extinction due to their racial defects-were used to justify government actions to dispossess Māori of their whenua (through military, legal, and economic measures) (New Zealand Parliament 1858). The writings of one journalist from September 1863 offers insights into how settlers perceived the Waikato-Waipā delta and the ways in which the discursive erasure of Māori economic activities and physical presence in the district served to justify settler state interventions to dispossess Māori:

The most painful feeling is produced by the sight of rich plains of immense extent, capable of profitable cultivation, with comparatively little trouble and expense, lying waste and unoccupied, while thousands of ready hearts and hands in the old country [Britain] are wanting the means of subsistence. (Unknown Author 1863)

He argued that mass migration of "thousands, and tens of thousands, of industrious and necessitous [English] country-men into the fertile

\footnotetext{
${ }^{1}$ Naboth's vineyard is a biblical reference to the Old Testament (Book of Kings), the bible story tells of Naboth was a citizen of Jezreel who was executed by the Queen so that her husband could take possession of Naboth's vineyard.
} 
plains of the Waikato" would ensure that the remnant Māori population would soon be "swamp[ed]" and the lands "rapidly brought into cultivation" (Unknown Author 1863). Such narratives, which linked together race-based theories (that Māori and other Indigenous peoples were "doomed" to extinction) with the socio-political and economic agendas of settler-colonial capitalism, positioned the land as lying unused awaiting the arrival of hardworking white settlers (specifically white men) to prune, plant, and develop the land, waters, and resources. Such settlercolonial stories of undeveloped landscapes, told and re-told in settler societies (including Aotearoa Australia, Canada, the United States), were notable for what they were missing, with the presence of Indigenous inhabitants often only mentioned in regards to their former presence, their depopulation, and failures (be it to cope with civilisation, to manage and develop resources) (Edmundson 2019; Ellinghaus 2006; Kelm 2005; McGregor 1997; Wolfe 2006).

Colonial media and government officials' writings increasingly imagined the Waikato lowlands as a future agricultural arcadia for settlers (not Māori), a so-called "Britain of the South", with no room in these accounts for mention of wetlands (Hursthouse 1861). Prior to the invasion published or unpublished records of settlers, missionaries, or colonial officials did not prominently (if at all) make mentions of wetlands (peat, mire, swamp, bog) (Hammer 1991; Howe 1970; Morgan 1862, 1864; Unknown Author 1859, 1867). Sometimes Pākehā travellers recounted how during their journeys along the Waikato and Waipā rivers how their canoes (waka supplied by their Māori guides) became stuck in muddy areas and they (following the lead of their Māori guides) were forced to wade through water and mud (Unknown Author 1859, 1862; Von Hochstetter 1867). However, these were brief interludes to narratives that focused on the ample natural resources that awaited Pākehā occupation and the seemingly limitless potential for agricultural development. As one visitor wrote the land around Te Awamutu reminded him more of "England that any part of the colony I have seen: the level plains and gently sloping rises, ... add beauty to the would, if all under cultivation, be a second Leicestershire" (Unknown Author 1864b). Such descriptions were often tantamount to wishful (one cannot say hopeful) imaginative geographies. They were (and are) a mode of envisioning landscapes and 
waterscapes that underpinned the entire history of settler-colonial projects (S. Dench 2011).

The representations of the Waikato and Waipa floodplains as being unoccupied and unproductively used land epitomises the settler-colonial gaze. It was (and is) a vision, on the one hand, that dismissed the legitimacy of Māori occupation, livelihoods, and way of life (see Fig. 4.3). On the other hand, they saw an entire settler-colonial body politic to come, which included the establishment of townships, infrastructure, and institutional arrangements, and everyday practices associated with colonial governance and the built environment. Thus, a settler-colonial polity to come was being imagined and projected onto the visual field of the Waikato in 1863-1864 as warfare in the Waikato was still ongoing. The map of Queenstown (later renamed Newcastle before reverting once again to its original Māori name of Ngāruawāhia) attests to how the settler gaze first erased. Indigenous wetlands, places, names, and bodies on paper even before the physical process of removal was completed (via the military invasion, confiscation of Māori land, drainage of wetlands, and construction of new township).

The surveying, naming, and roading layout of the township of Ngāruawāhia, located where the Waipā River joins the Waikato River, is a case in point. The location was (and remains still) the centre of Kingitanga movement and is the traditional lands (rōhe) of WaikatoTainui iwi (see Chap. 3, Fig. 3.1: Map of the location of hapū and iwi). During the invasion, the site was used as a military encampment, and later the area was carefully laid out by surveyors in the shape of the Union Jack (see Fig. 4.4: Map of Queenstown). The inscription one of the most obvious symbols of British sovereignty on an area of profound cultural, political, and spiritual significance for Waikato-Tainui Māori and other groups affiliated with the Kinngitanga movement was an assertion of colonial power. It was part of wider efforts to erase Māori history, values, and rights, and more specifically to erase Waikato-Tainui rangatiratanga (which breached article two of the Treaty/Te Tiriti). The roads were laid out in neat, straight lines and given names that reflected British (in keeping with Anglo-Saxonism discourse) colonial power. On the map there is no sign of wetlands nor Māori (past, present, or future) presence; just as Māori was rendered out of place in the settler-colonial order of things, so 


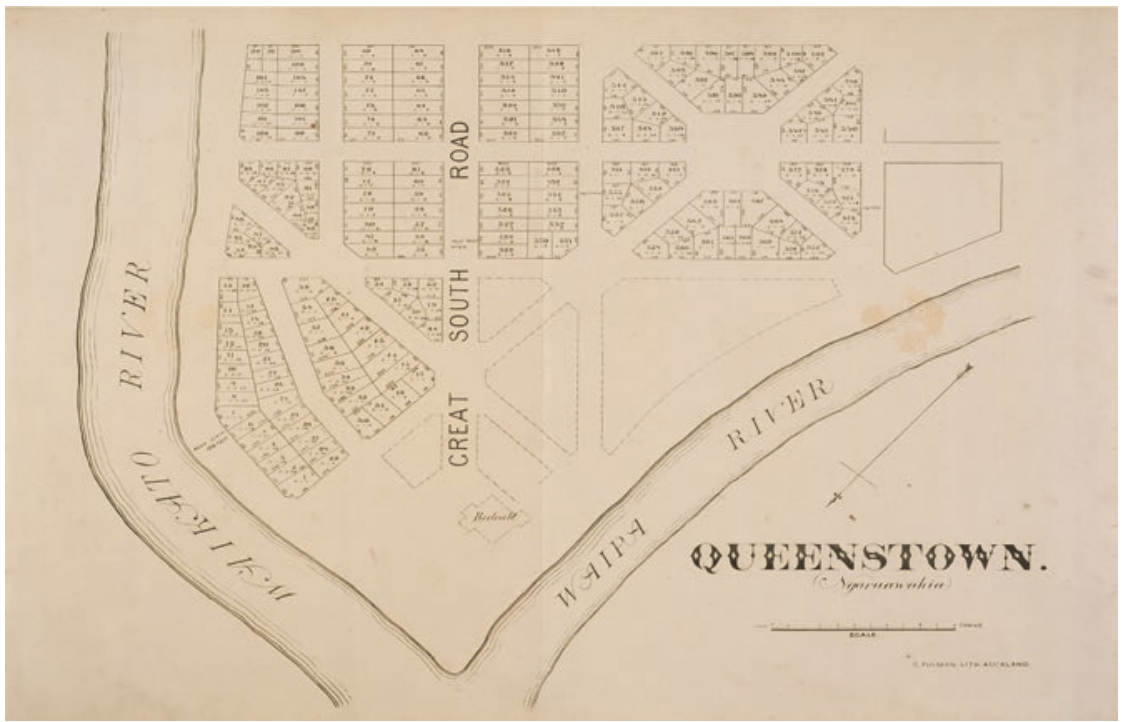

Fig. 4.4 Map of Queenstown (Ngāruawāhia) showing allotments for sale in 1865. (Source: Auckland Libraries Heritage Collections NZ Map 4498-22)

too were wetlands. Yet, the straight, fixed, and well-defined lines on a map did not accord to the reality of life on the muddy, swampy, unstable, and porous ground of the newly confiscated lands. Just as the wetlands did not simply disappear because of colonial displeasure so too Māori presence within the area was not erased despite colonial violence and confiscation, both the continuation of mud and Māori created continued anxieties amongst Pākehā. Such maps both were a product of and reinforced settlers' imaginative geographies of the Waikato. Maps and surveys, as the works of historians' and geographers' demonstrates (Brealey 1995; Byrnes 2001; Cameron 2011; S. J. Dench 2018), were (and still are) modes of envisioning landscapes and waterscapes that formed a critical part of settler colonialism. While wetlands were absence from preinvasion accounts of the plains, British military officials did note the presence of wetlands in the Waikato-Waipā Delta posed difficulties to soldiers and drew maps that indicated the presence of wetlands (see Figs. 4.5 and 4.6). 


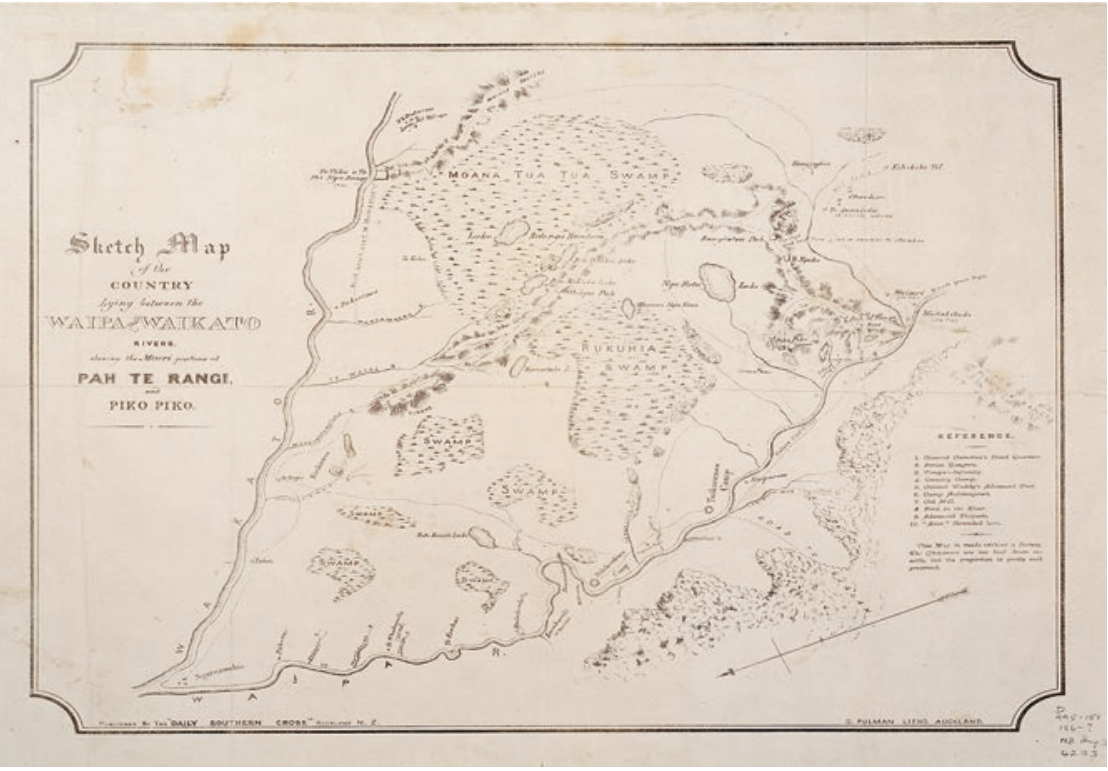

Fig. 4.5 Sketch Map of Waipā and Waikato Rivers showings some of the wetlands in the lower section of the Waipā River (note Ngāruawahia at the meeting point of the Waipā and Waikato Rivers). (Source: Auckland Libraries Heritage Collections NZ Map 4273)

\section{Post-Invasion Realities: Life on/in the Wetlands}

In the aftermath of military invasion of the Waikato (1864 onwards), the land confiscated from iwi was surveyed and subdivided into freehold blocks for lease or purchase by Pākehā settlers (either single or married men). And the extensive wetlands could no longer be overlooked as surveyors and settlers walked on and waded through the water and mud (Cowan 1928; Unknown Author 1865a, 1865b). British imperial soldiers were given the option of taking up a land grant (with the amount of land awarded based on rank and length of service); with three years of "good" service allowing rank and file soldiers (privates) to obtain 50 acres of land in the Waikato (Hamilton 1968; McLellan 2017). Approximately 60,000 hectares were subdivided into land in and around the military settlements of Alexandra (Pirongia), Kihikihi, Whatawhata, Cambridge, 


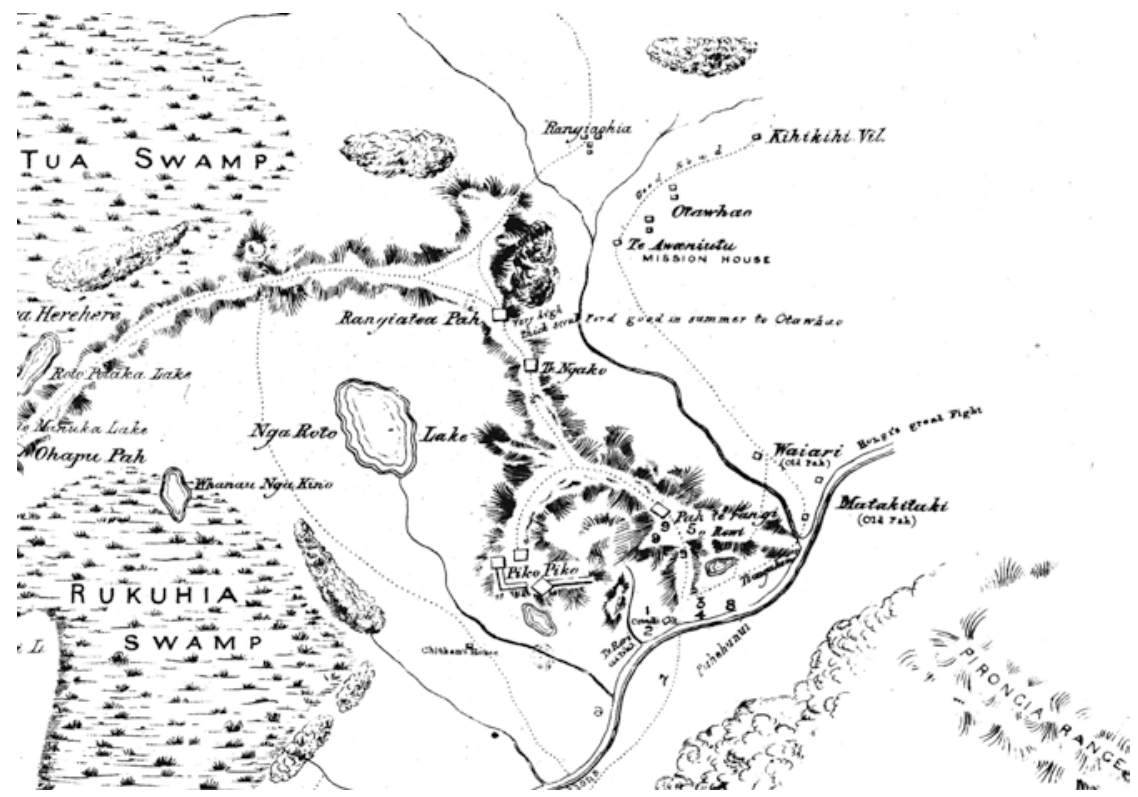

Fig. 4.6 Showing details of Map 5 including part of Ruakuhia wetland (left), Lake Ngāroto (centre-left), Piko Piko as well as other Māori pā, and Otawhao mission is also recorded (centre-left). (Source: Auckland Libraries Heritage Collections NZ Map 4273)

and Kirikiriroa (Hamilton); other parcels of land was also sold to former soldiers. The newly surveyed land, however, did not always accord to the previous agrarian utopian descriptions of missionaries, government officials, and travel writers, and most soldiers walked off their land declaring too swampy (McLellan 2017). In her memoir, Bernice Monrath Johnstone, for instance, recounted how her father purchased their family's 50-acre farm, situated alongside the Mangapiko Stream between Te Awamutu and Pirongia, in the late 1860s from former soldier "who was eager to get away from the close vicinity to Maori camps, settlements, and the King Country, and glad to pass it onto someone more courageous than himself" (Johnstone and Roberts 2004, p. 9). She recalled that both she and her mother found serious fault with the farm due to its isolated position (with few Pākehā farms in the vicinity) and it was "more waste land than farmed land-acres of swampy bush country, acres of 
fern, and acres of scrub". The "sandy piece of land" was broken up by the "Mangapiko Stream [which] twisted and turned forming boundaries of narrow points and sharp bends ... [with] more than half the farm ... broken into by many swamps" (Johnstone and Roberts 2004, p. 14).

Many settlers similarly complained about their newly acquired lands with a litany of objections listed in letters to newspapers and politicians about the deficiencies of sections they obtained (by grant, lease or purchase) from the central government. In contrast to the earlier depictions of fertile and prosperous lands by travel writers and members of the media, Pākehā settlers found "swamp or ... springy flax flats", which were frequently impassable due to heavy rains (see Fig. 4.7) (Unknown Author

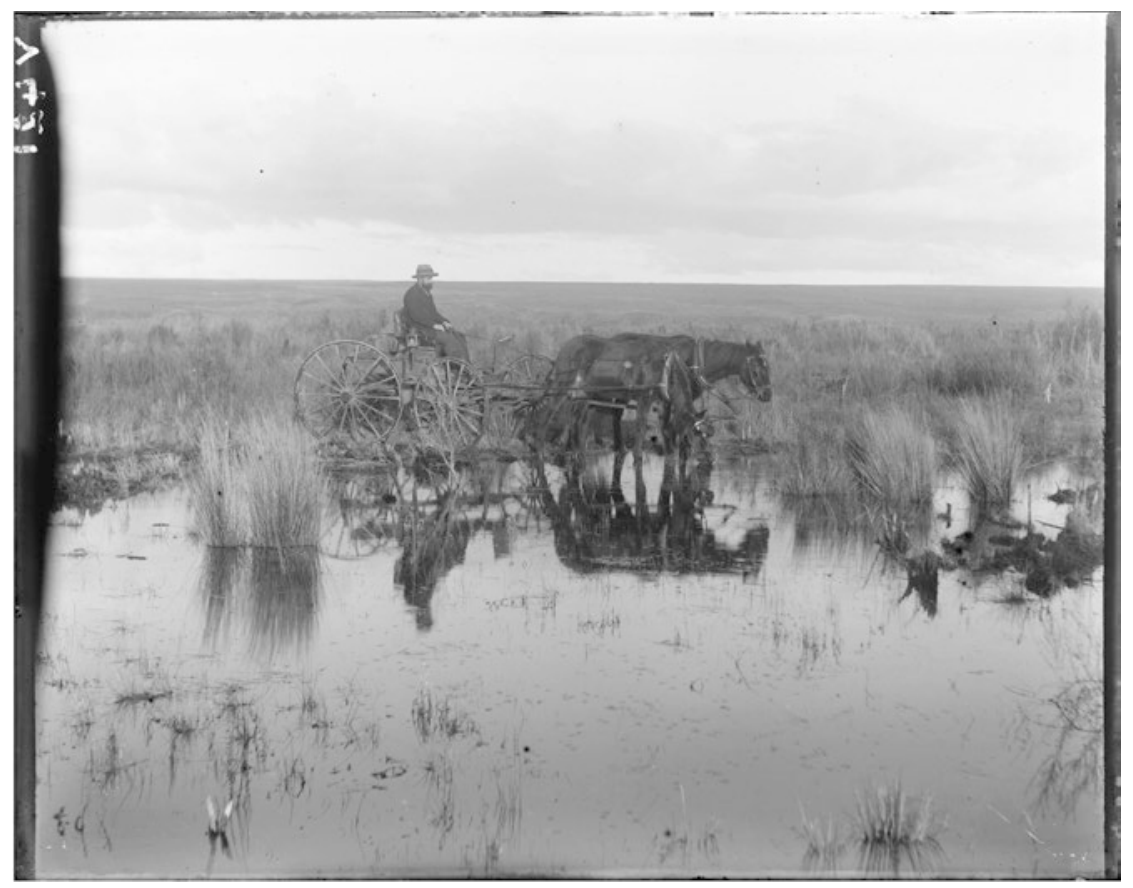

Fig. 4.7 Horse and cart journey across the wetlands of the Waikato-Waipā delta (circa the 1880s). The area is probably located of the property known as the Broadlands owned by Hubert Valie (along Waikato River rather than Waipā). Still, it does give a good indication of what the landscapes/waterscapes looked like before drainage work. (Source: Auckland Libraries Heritage Collections 2-V421) 
1864a, 1864c, 1865b, 1865c). Some declared that they were being forced into "bastard system of farming" that was not "convenient nor healthy"; they narrated their efforts to farm on the swamp-filled grounds of the Waipā and Waikato rivers as alike to a battle against inevitable financial and physical ruin (Unknown Author 1865c). The task of digging drains and removing the wastelands of "black, cold swamps" was something that was often declared by experts and settlers alike both as tiresome and potentially deadly and undesirable work for people (specifically white men) to perform (Unknown Author 1887, 1909). One journalist declared only a special type of man, a "swamper", was capable of such work (see Fig. 4.8). Swampers, the writer declared, possessed the necessarily carelessness with his health to be able to withstand the process of transforming the wetlands into farmlands. Daily activities of "walking through the damp rushes" in "stinking water", "cutting and lifting masses of dripping peat" were all supposedly hazardous to one's health. The men who worked to drain the wetlands were supposedly left physically drained of strength; their health eroded from working in the unhealthy (potentially malariafilled and miasmatic) atmosphere that left them with "rheumatism and sciatica" (Unknown Author 1887). The smells of wetlands of decomposing vegetation, of sulphur (which indicates anaerobic processes), were not only off-putting for Pākehā but due to their sanitary and miasmatic understandings of disease-causation directly linked to ill-health and potentially death. Despite the discovery of bacteria and the emergence of bacteriological science in the mid-nineteenth century, most doctors and settlers in Aotearoa continued to believe that miasmas (bad airs) caused ill-health. Miasmas abounded in diverse and highly uncertain ways (through decomposing matter, foul air, strong odours, human and animal waste, stagnant water, factories, particular environments) (J. Beattie 2008; Chiang 2008; Flikke 2016; Halliday 2001; Kiechle 2017; Parsons 2019; Worboys 1994). The stench of composting vegetation and animal matter, and peaty soils, all of which were found in abundance within the Waipā wetlands were read as persistent threats to one's health. Accordingly, settlers (or their descendants) increasingly sought to employ non-white people ("the Other" if we employ the theoretical concept from Edward Said's seminal work Orientalism) most commonly Māori but also sometimes non-Māori non-British people (including Croatian and Chinese) 


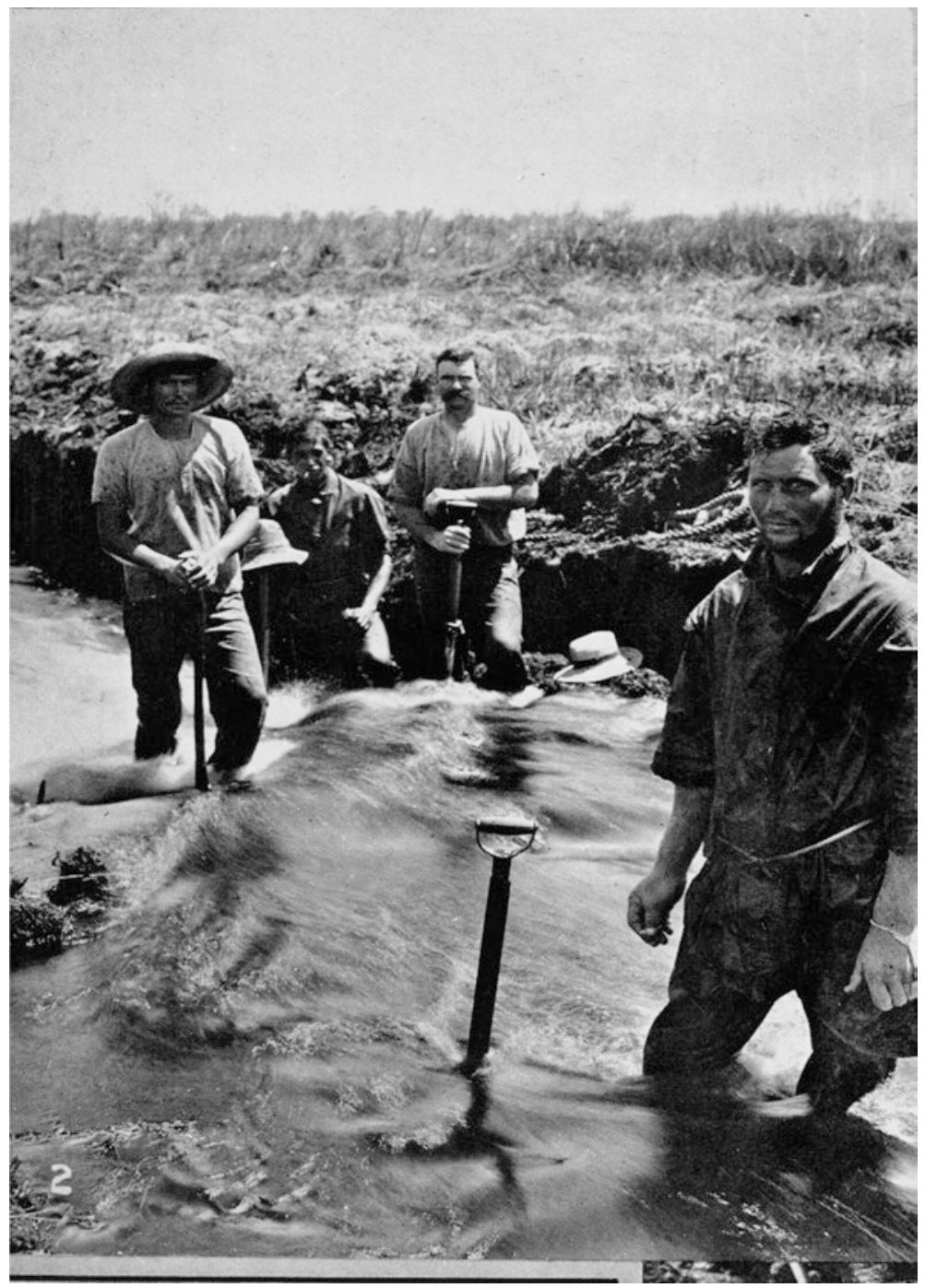

Fig. 4.8 Swampers digging a drainage canal through a wetland. (Source: Auckland Library Heritage Collections NZG-19100209-28-2) 
to dig the drains and farm the swampy lands (Said 1978); as they (Other "races") showed an "aptitude for horticulture" (St. John 1873), was cheaper to employ, was unconcerned about the dangers of miasmas, and were supposed gravitated towards nomadic lifestyles (Johnstone and Roberts 2004; Jones 1996; McGovern 1986; Meyer 1996). Indeed, the canals, flood levees and roads that now define the Waipā floodplains were constructed on land confiscated and/or acquired from Māori and built by Māori labourers; yet, Māori also actively opposed and mounted protests against such works.

At the same time as Māori were being employed to drain wetlands to facilitate settler projects to transform swampy grounds into pastures, doctors blamed Māori ill-health (with mortality and morbidity rates far higher from Māori than Pākehā) on Māori unhealthy practices of living and working on or near wetlands (AJHR 1875, 1885a). These ideas, as we outline in our other works, were infused socioeconomic, medical, and race-based theories that justified Indigenous dispossession and drainage works. Such theories reinforced the longstanding prejudices that many settlers held about both Indigenous peoples and wetlands as being need to undesirable and an impediment to settler-colonial progress (Carlson 2010; Parsons and Nalau 2016; Parsons 2019) (Fig. 4.9).

The abundance and vagueness of miasmas (with no clear boundaries between airs, lands, waters, and bodies) meant that miasmatic thinking about disease-causation continued to influence settler-colonial understandings of wetlands throughout Aotearoa. In the Waikato, Pākehā doctors and government officials in the late nineteenth century sought to reassure the Pākehā public that their health and wellbeing was secure, despite the continued presence of large wetlands areas and neighbouring Māori communities within Rohe Pōtae (Unknown 1876). Race and environmental health were interwoven together, with Nevertheless, outbreaks of "typhoid fever and colonial fever" in the district in 1876 were reported by the Waikato Times newspaper as "due doubtless to the heavy rains of early summer, followed by great heat, generating miasma", with similar climatic conditions and fevers recorded in 1860 (Unknown 1876). Elsewhere in the country, high mortality rates were ascribed to building houses out of green timber, on undrained land, and climatic changes in the area. The omnipresent dangers of "damp vapour arising" 


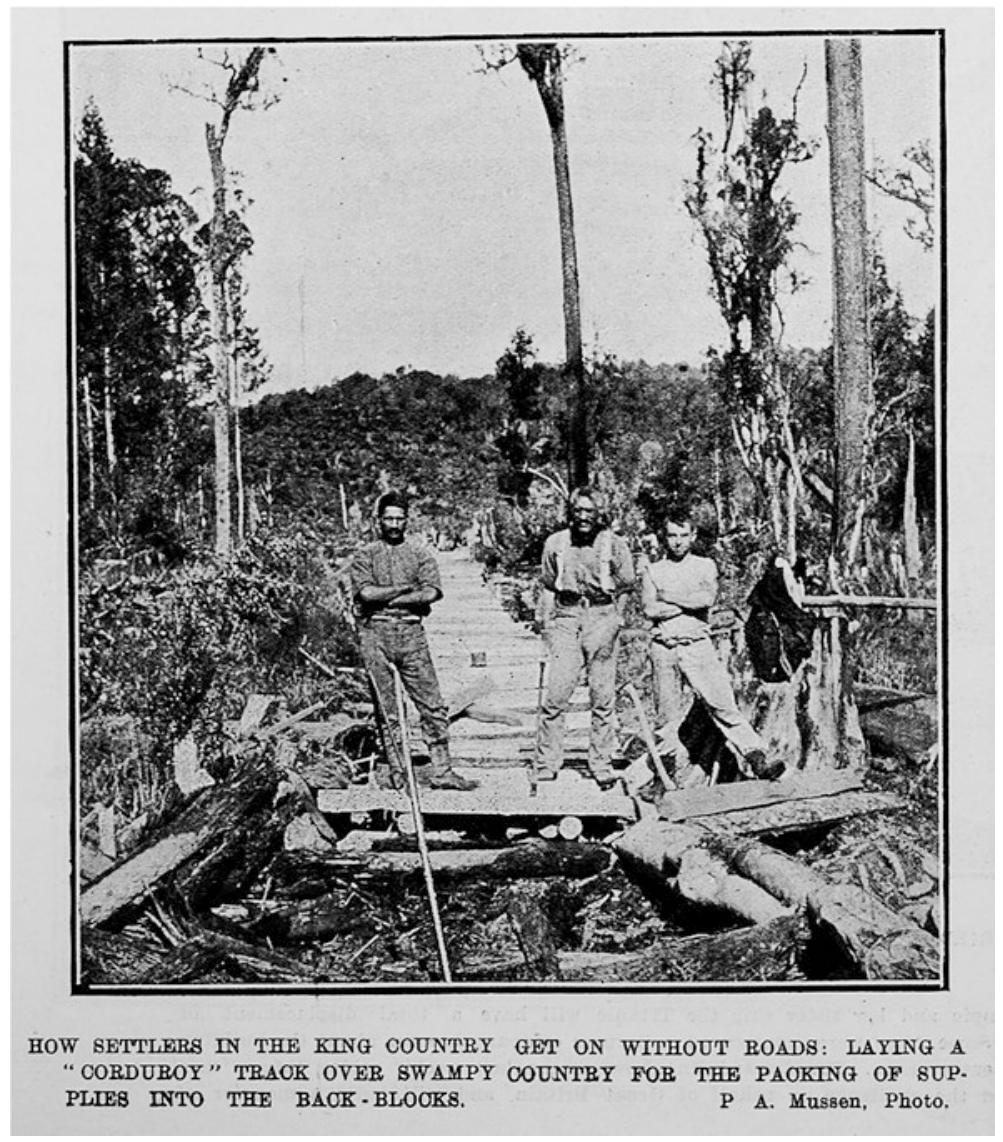

Fig. 4.9 Two Māori workers and a Pākehā boy constructing a road in the King Country/Rohe Pōtae (circa 1910). (Source: Auckland Libraries Heritage Collection AWNS-19101124-6-5)

were deemed "highly prejudicial to the health" of residents (AJHR 1875, p. 20). In 1875, for instance, the population of the township of Napier in the Hawke's Bay (North Island) experienced an outbreak of a "fever" (incorrectly labelled malaria) which was blamed by officials on the "noisome emanations from the swamp" beside the town (Unknown Author 1878a). The "tepid swamps", it was reported, poisoned the "otherwise pure air" and ruined "health, retard[ed] settlement, and br[ought] 
hundreds to an early grave" (Unknown Author 1879). In total, the deaths of 140 people in Napier (out of a total population of 3000) were linked to the 1875 fever epidemic. In 1875, the New Zealand Parliament introduced the first legislation that specifically authorised wetland drainage. The Napier Swamp Nuisance Act enabled local government officials to "fill in" (meaning to drain, establish levees, and build up the soil) any parcel of land deemed to be a muddy watery "nuisance" without the consent of the landowners (New Zealand Parliament 1875). While the 1875 legislation did not mention a specific disease, the legislation and discussions surrounding it (in parliament and newspapers) highlighted Pakehā perceptions of wetlands as spaces of noxious airs, unruly waters, and unproductive flora and flora (Unknown Author 1879). The Napier experience similarly influenced perceptions of the wetlands of the WaikatoWaipā Delta and saw more calls from Pākehā for specific local and central government support for wetland drainage works. Wetland drainage was not only meant to provide Pākehā with economic security but also with significant health benefits through the eradication of dangerous diseaseinducing miasmas (J. Beattie 2008; J. J. Beattie 2005).

Exotic tree plantings were, alongside digging of drainage canals, essential steps that settlers needed to take to eradicate the hazards posed by wetland living. In April 1876 a correspondent for the newspaper Waikato Times to praised the planting of "double rows of pinus insignus and eucalyptus" in Ngāruawahia (see Fig. 4.10). The exotic trees, the unnamed commentator wrote, were not only aesthetically pleasing but also vital preventive health aids to purify the air from dangerous odours (Unknown Author 1876a). The newspaper published follow up articles that promoted the planting of eucalyptus trees as to act as an "active purifier neutralising the miasma of the atmosphere and absorbing the superabundant moisture below the surface" (Unknown Author 1876b). These newspaper articles sought to encourage other Town Boards in Waikato to follow the example of Ngāruawahia and plant trees to improve the health. Women in the Waikato were likewise encouraged plant "the most odorous flowers" (Unknown Author 1875) including "lavender, musk, cherry laurel, clove, fennel, narcissus, heliotrope, hyacinth, and mignonette" that were supposed "endowed with health-preserving properties" that could remove miasmas from the air (Unknown Author 1873). Accordingly, 


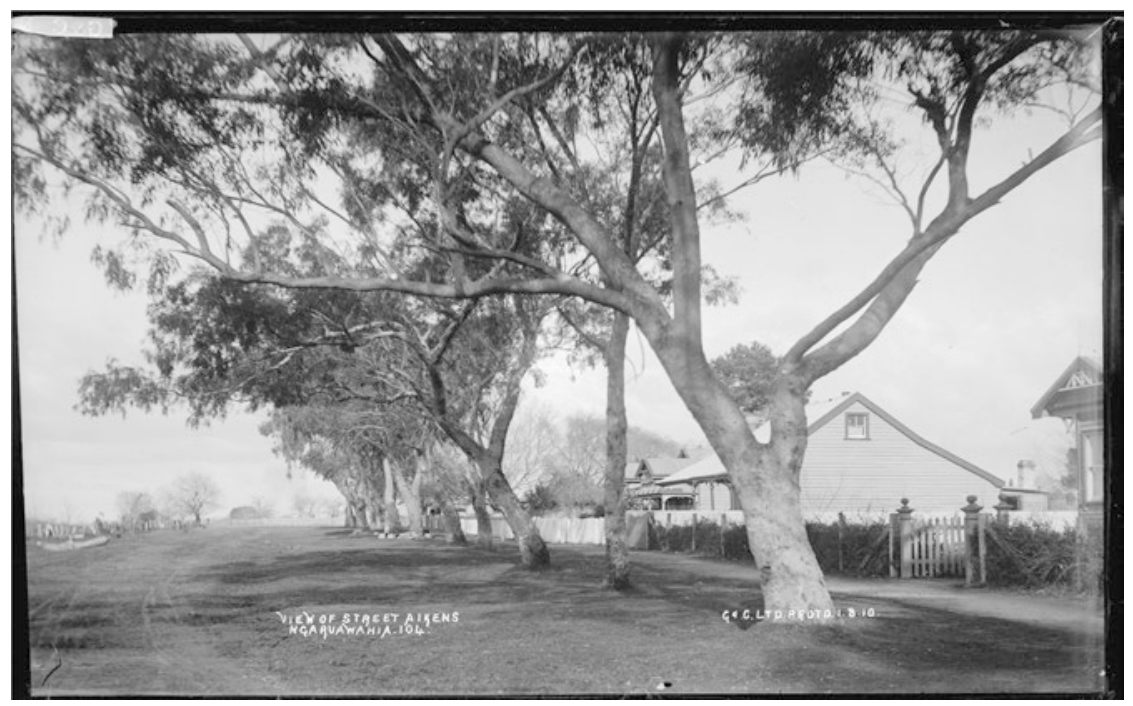

Fig. 4.10 View of Aikens Street in Ngāruawahia (1910) showing a row of mature eucalyptus trees in front of the houses on the right side of the road. (Source: Green \& Colebrook (Firm). Aikens Street, Ngāruawahia, 1910—Photograph was taken by G \& C Ltd. Ref: 1/2-000256-G. Alexander Turnbull Library, Wellington, New Zealand)

the cultivation of flowers was deemed critical work that served to be "delightful and humanising in itself, but one which in a way ... confers a positive benefit on society so great that it can hardly be overrated" especially in areas where there were much poisonous (miasma-filled) airs (such as in large towns and muddy swamps) (Unknown Author 1875). Every Pākehā woman, one author declared in 1873 (paralleling the sentiments of other writers), should surround her dwelling with "sweetscented flowers and plants", and who ensured "her rooms fragrant with their essences, [was] an angel of health to her family" (Unknown Author 1873).

While Pākehā men were (supposedly even if others overlooked who actually undertook the labour) responsible for ensuring that lands were cleared of Indigenous biota, drained, and remade into neo-British farmlands, Pākehā women were charged with the tasks of ensuring that homes and families were kept healthy through domestic hygiene practices 
(cleaning, cooking) and planting sweet-smelling home gardens (Unknown Author 1873, 1875, 1885). Such individuals actions to transform spaces from hazardous to healthy were, thus, narrated as an essential part of raced and gendered discourses that circulated within Aotearoa and other settler-colonial societies that emphasised that the Indigenous landscapes, waterscapes, modes of life, dress codes, and even bodies were deficient and needed to be fundamentally changed. One journalist in 1878, during a boat journey up the Waipā River, described his impressions of the Māori and Pākehā who lived at the small village of Whatawhata in highly racialised and gender terms:

Here ... the two races dwell together in brotherly and sisterly love. Maori and half-caste gamins and 'young colonials' mingle together on the sand of the riverbank and vie with each other in [the] exercise of sound lungs. There a wahine [Māori woman] squats on the extreme verge of the precipice with her pickaninny [sic] carried on her back in a blanket watching her other 'young barbarians all at play;' and just far enough off to preserve pakeha [sic] feminine dignity, is a settler's wife attired in something that looks like silk, and sheltered under a parasol. ... conveys a whole volume of testimony to its civilisation. (Unknown Author 1878b)

The diaries, letters, oral histories, and published accounts (in newspapers, memoirs, and magazines) of Pākehā men and women, who visited and lived in the floodplains of the region, often recounted feelings of fear and despair; with concerns about their new wetland-filled homes intermingling racial, social, medical, and economic anxieties. They wrote accounts - in diaries, letters, memoirs, reports to government, letters to editors - filled with their fears of miasmas, the imagined threats posed by Māori (their resistance, return, violence), the economic difficulties of land conversion, and the desperate need to progress the land and themselves onwards and forwards through acts of 'unwatering' the land and bringing civilisation (defined as "life" itself) to the stagnant lands and waters that surrounded the Waikato and Waipā Rivers (Henderson et al. 1994; Johnstone and Roberts 2004; Jones 1996; Kerry-Nicholls 1884; Savage 1847; Unknown Author 1878c, 1887; Westmacott 1977). As one Pākehā man wrote of the wetlands in 1887 : 
If I were to paint desolation, if I was to plant as dreary a picture as I could of lifeless gloomy colouring, I would depict the scene before me now. I am in the great swamp region of the Waikato, and before me stretches a wide expanse of stagnant water. (Unknown Author 1887)

Similarly, Margaret Macky, who grew up on a farm beside the Waipā River (near the township of Te Awamutu in the 1870s) recalled her childhood home as one: "with its lowland peat swamp terribly lonely and depressing" and "eerie ... with the stumps of bygone forests covered with ... rushes poking through the rain" (Henderson et al. 1994, p. 85) (See Fig. 4.11). However, she later recalled how the work of her parents and other "pioneers" transformed the "depressing" swamps into the "beautiful district is now ours" (Henderson et al. 1994, p. 85). Macky, like others, about employed the dominant settler-colonial narrative:

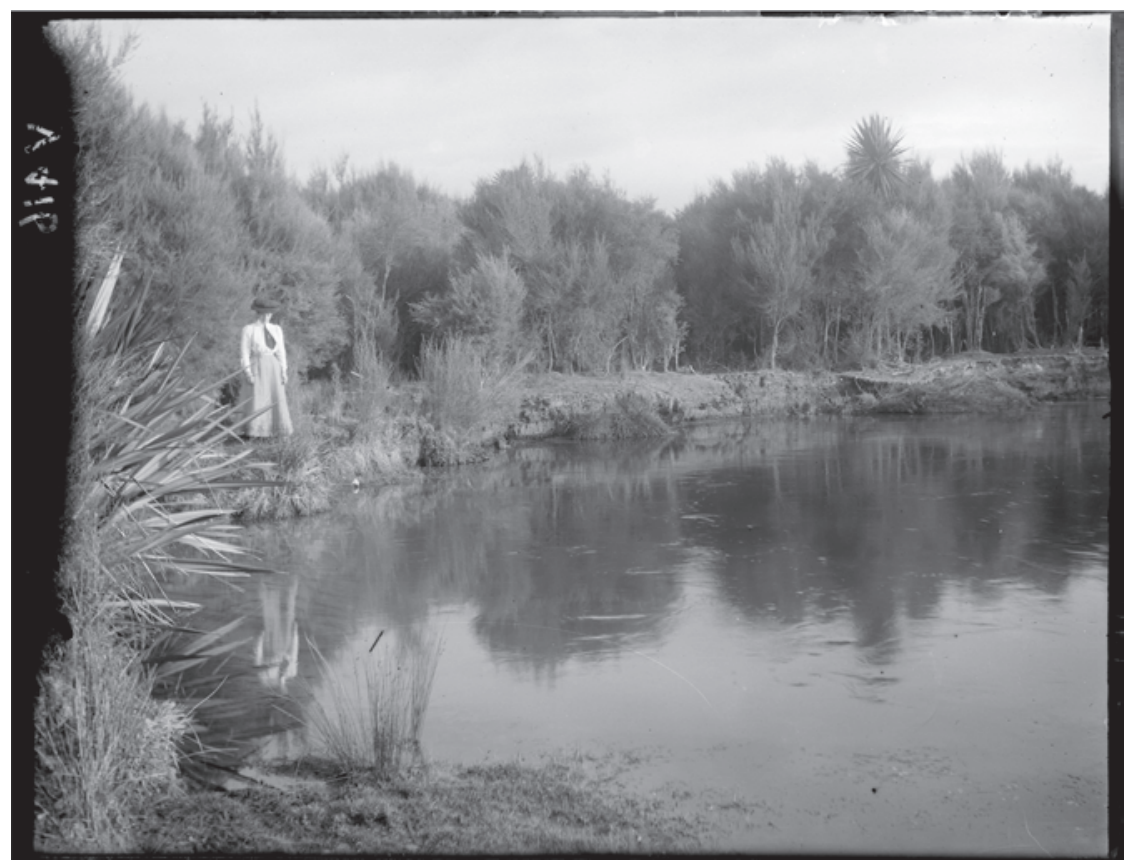

Fig. 4.11 Woman standing beside one of the peat lakes within the wetlands of Waipā. (Source: Auckland City Libraries Heritage Collections, 2-V416) 
settlers arrived in the wilderness; "battled" against nature (Indigenous); and ultimately created order (modernity, capitalism) out of chaos (nature and subsistence-based livelihoods) and in doing so created economically productive communities (Cumberland 1941; Guthrie-Smith 1969; Levy 1970; Parsons and Nalau 2016; Thomson 1867). Such a narrative was not only linear but also transformative in effect and emphasised the radical reconfiguration of social and ecological communities.

Throughout these earlier accounts (by self-described "settlers" or "pioneers") of wetlands the overwhelming narrative employed by Pākehā settlers was one of detachment (rather than an attachment) to place and the ways in which the existing wetland environment was at odds to their understanding (and preference) of what constituted a healthy, productive, and secure lands and waterways to live, work and play in. Many individual settlers wrote about the enormity of the task they faced transforming "the dreary waste of rushes" into "anything beautiful". Beauty from the gaze of settlers (who often described themselves as "AngloSaxon") consisted of "verdant pasture" capable of bearing the "weight horses, cattle, and flocks of sheep" (Unknown Author 1887). Settlers declared that "even this dreary wilderness" of apparently useless wetlands could be remade by hardworking (Pākehā or Anglo-Saxon) settlers "into a scene of smiling pastures and spreading fields" through drainage and planting works (Unknown Author 1887) (see Fig. 4.12). As one Pākehā settler wrote in 1883 that while the "original state" of the environment was a "sombre and disagreeable impression" actions could and were being taken by individuals to remove supposedly unproductive Indigenous vegetation and plant grains and grasses to "impart a pleasing beauty to the landscape" reminiscent of the best of England (Barugil 1883). Such imaginative geographies provided the emergent settler-colonial state in Aotearoa as well as individual settlers' with the belief that their actions (of invasion, violence, occupation and radical changes) were all morally justifiable. 


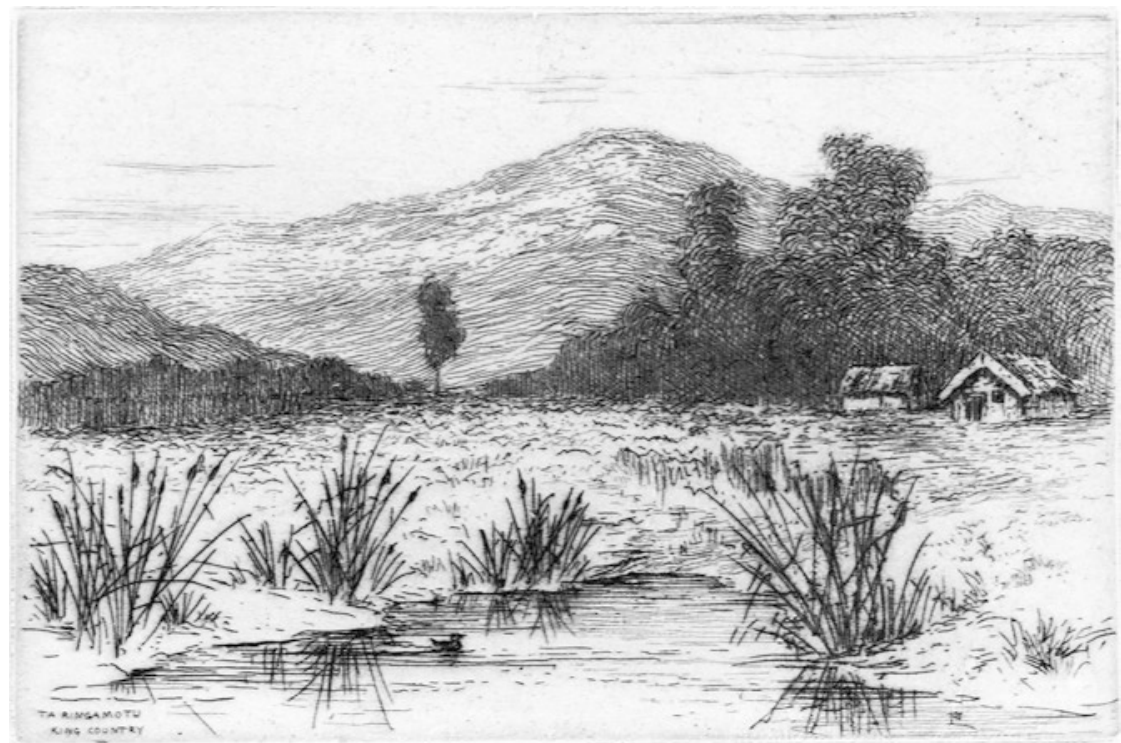

Fig. 4.12 Sketch drawing of wetland "Ta Ringamotu" in Te Rohe Potāe (King Country) 1888. (Source: Ref/A-045-003. Alexander Turnbull Library, Wellington, New Zealand)

\section{Māori Engagements with Wetlands and the Settler-Colonial State}

In marked contrast, Ngāti Maniapoto and the Kīngatanga allies they were hosting within their rōhe, in the upper and middle catchment of the Waipā River (Rohe Pōtae), held vastly different understandings of wetlands that centred on their tikanga (customary laws) and mātauranga Māori. Màori conceptualised themselves as the kaitiaki (guardians) of their whenua, awa, repo and sought to practice kaitiakitanga (environmental guardianship) despite the slow violence of settler-colonialism. Local hapu continued to be responsible (under the customary laws of tikanga) for practising kaitiakitanga as a way to ensure the health (hauora) of all who lived there; this included the critical need to maintain the lifeforce-mauri-and wairua — spiritual integrity—of both human and ecological communities both now and for future generations. In addition 
to employing mātauranga Māori (Māori knowledge), many Māori sought to engage with Western knowledge and practices and attempted to use the British legal system as a way to practice kaitiakitanga and ensure their modes of life, mauri, wairua and tikanga were maintained despite the onslaught of settler-colonial domination and ecological violence.

In the 1880s, as part of negotiations between the Crown and Ngāti Maniapoto about the proposed railway line, Ngāti Maniapoto rangatira (chief or high rank) sought to ensure specific agreements were reached to protect its wetlands and forests from damage. While both Māori and English versions of the Treaty of Waitangi included a provision (Article Two) that required the Crown to actively protect Māori land, forests, and other taonga (treasures), Ngāti Maniapoto leaders were well-aware by the 1880 s that the Crown was not honouring its Treaty promises. Accordingly, its leaders attempted to implement a specific accord that would ensure that the construction of the railway line through Rohe Pōtae would not negatively impact their wetland taonga. Rangatira Hopa Te Rangianini, for instance, demanded reassurance from the Native Minister (John Ballance) in 1885 that the railway would not destroy his mahinga kai (food gathering sites). Ballance reported this back to parliament:

He [Hopa Te Rangianini] owned a swamp, over which the railway would pass, and he obtained eels, which were his principal food in summer, from this swamp. He said he had heard that in England railways were taken over viaducts, and he asked that this might be done in this case, instead of filling up the swamp. (AJHR 1885b, p. 23)

Likewise, rangatira Aporo Taratutu argued that certain trees also needed to be conserved because of their importance as food sources. He informed government officials that only specific native trees should be logged and used in construction work; they were permitted to use matai trees for railway sleepers, but kahikatea trees needed to be retained "because in summer he used the berries for that tree for food" (AJHR 1885 b, p. 23). Minister Ballance informed parliament that the government would be constructing viaducts (see Fig. 4.13: Train over the valley) 


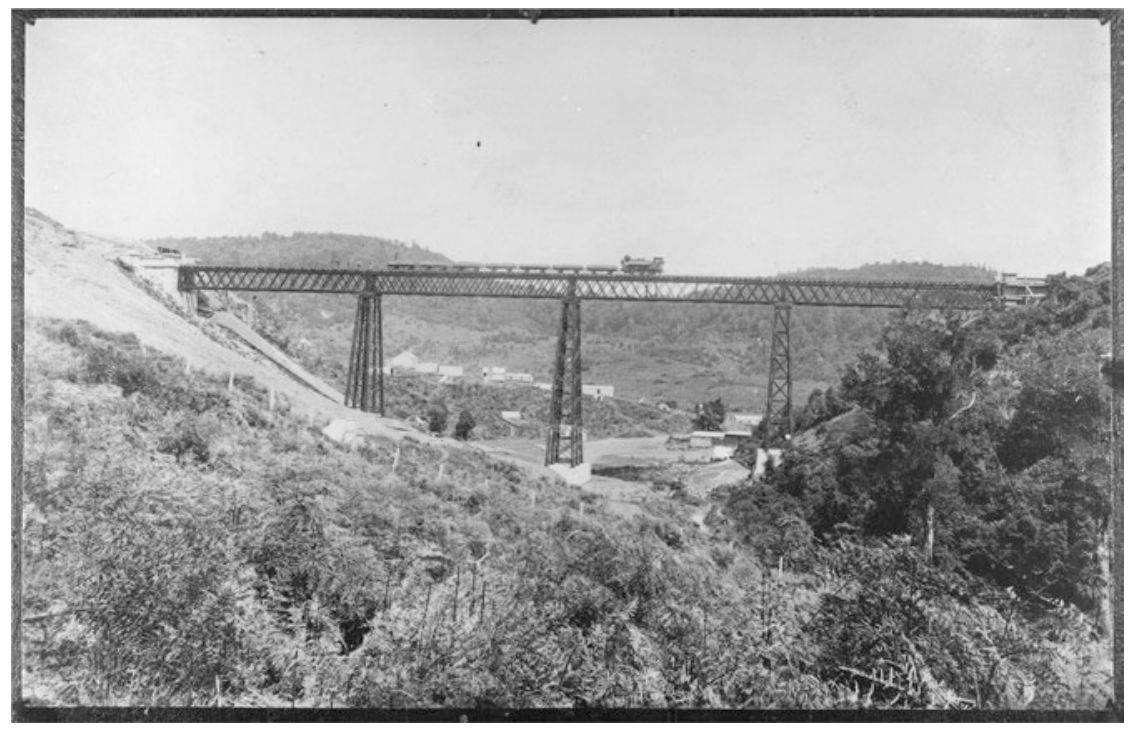

Fig. 4.13 Train crossing the Waiteti Viaduct, near Te Kuiti, circa 1890. Note the clearance of vegetation and the construction of roads and buildings below the viaduct, which indicates that the government's promises made to Māori to protect wetlands were completely disregarded. (Source: Auckland Libraries Heritage Collection, 4_1078)

in Te Rohe Pōtae, but for reasons of modern engineering and travel-time efficiency for rail journeys rather than in response to Māori demands.

Minister Balance dismissed iwi concerns about their so-called primitive food sources as nothing more than anxiety that would soon be erased by the money that would roll into the district alongside the trains.

I agree[d] ... that the watercourses should not be interfered with; but ... Something has been said about eating berries from trees, and so on; but let me tell you that the money will come to the people through the construction of this railway will be worth all the berries in the world, and the eels, too. (AJHR 1885b, p. 24)

Ballance's comment highlighted the fundamental differences between Māori and Pākehā worldviews and modes of life. The dominant values of Pākehā settler society (for which Ballance was a keen illustration) drew on 
longstanding European post-Enlightening binary thinking that sought to divide human and non-human and culture and nature and preached the sectarian gospel of Victorian technological advancement and economic development. Ballance, like many other colonial officials in Aotearoa and other settler societies, valued the accumulation of goods (including land and money) above all else. The threats and acts of violence, committed by settlers against Indigenous and other non-European societies, were regularly downplayed as unavoidable consequences of the urgent necessities of 'progress', 'improvement' and 'development'.

Many members of Ngāti Maniapoto expressed their strong desires to maintain their modes of managing their taiao (environment), opposed the activities of the Native Land Court (NLC) to convert their whenua into European-style land titles, and actively challenged efforts to alter their relationships with their whenua, awa and repo. When the first surveys were being conducted for the railway line through Rohe Pōtae in 1884, for instance, a group of Ngāti Maniapoto wahine protested against the Crown's intrusion into their territory by removing all the survey pegs and throwing the surveyors' equipment into the Waipā River (Unknown Author 1884 , p. 2). By the 1890 s, the NLC and the implementation of Europeanised land tenure arrangements began to cause ongoing tensions amongst extended kin groups (including whānau, hapū and iwi of Ngāti Maniapoto) in the middle and upper stretches of the Waipā River catchment. One Māori wahine and her whānau, after they received individualised land titles (after going through the NLC process) to land at Kakepuku (located between Te Awamutu and Otorohanga and including Te Kawa wetlands), erected fences around their newly surveyed and titled properties. However, other members of Ngāti Maniapoto challenged their claims of exclusive individual Pākehā-style land ownership (rather than Māori collective land rights) and removed the fences. The fenceremovers argued that they needed (and indeed possessed the right under Māori laws or tikanga) to access the land (irrespective of who held the title) as they needed to access the waterways to harvest tuna (eels). The owners, once again, chose to use the newly imported settler-colonial laws (rather than Māori laws or tikanga involving parties negotiating face-toface through hui-meeting) to support their land rights and issued a trespasser notice against other members of their iwi (Wilkinson 1892). 
By the 1900s, Māori were already an ethnic minority group in Aotearoa. Decades earlier, in 1840, when rangatira from around Aotearoa met, discussed, debated, and signed the Te Tiriti o Waitangi. In again in 1885 when leaders from Ngāti Maniapoto and other iwi met with and reached an agreement with the government (the NZ Crown) about the construction of the railway, Māori were still numerically dominant within Rohe Pōtae. However, by the early twentieth century the influx of Pākehā settlers, capital, largescale Crown land purchasing activities, the operations of the Native Land Court (NLC), and the extension of the countless institutional apparatuses of the settler state saw this demographical structure change in Rohe Pōtae; as had occurred earlier in other parts of Aotearoa. The world in which Ngāti Maniapoto tikanga, including their mātauranga, practices of kaitiakitanga and rangatiratanga, the cornerstones of life, were shifting on its foundations; if not a metaphorical earthquake, then a definite muddy of waters (to draw on an allusion to the wetlands we are discussing) for Māori communities as they sought to address, discuss, negotiate, engage with and clash over the ontological and epistemological implications of settler colonialism.

\section{Government Responses}

In response to Pākehā perceptions of wetlands as problematic, hazardous, and unproductive spaces, a series of acts of parliament were introduced which created and authorised government institutions to systemically drain the country's wetlands. The first legislation was Napier Swamp Nuisance Act (1875), which was followed by the Drainage Act in 1881 (New Zealand Parliament 1881) and the 1893 Land Drainage Act, which allowed for the creation of drainage schemes with government subsidies (New Zealand Parliament 1893). In the first decade of the twentieth century, a suite of different acts of parliament were introduced that established central government-led drainage schemes in the Rangitāiki Plains (Eastern Bay of Plenty) and Hauraki Plains (Waikato) (AJHR 1911, 1913; New Zealand Parliament 1908a, 1910) and local government drainage projects (New Zealand Parliament 1904, 1908b). The Land Drainage Act 1904 allowed for the establishment of local government 
bodies (drainage boards) specifically responsible for draining wetlands within their local areas. Each drainage board was to be made up of members who were elected by local ratepayers (landowners who paid local government taxes) (New Zealand Parliament 1904). Drainage districts, overseen by separate drainage boards, were quickly established in the Waipa River in the first two decades of the twentieth century. At least twelve operated in the Waipā River and its tributaries; nine in the middle and upper Waipā catchment (Kawa, Kio Kio, Awatene, Mangaorongo, Waipa, Mangawhero, Orahin, Waitomo, Mangapu) and three in the lower catchment (Lower Mangapiko, Upper Mangapiko, and Tua Tua Moana) (New Zealand Parliament 1924; Simmonds 1938; Tua Tua Moana Swamp 1915a, b; Unknown Author 1935, 1970).

Drainage boards were responsible for undertaking extensive works to remove and remake wetlands. Activities included the construction of drainage canals (by hand and by machine) the construction of flood levees (stopbanks), the realignment of watercourses so that each flowed in straighter lines, and the removal of pā tuna (eel weirs) and riparian vegetation. Throughout the late nineteenth and first half of the twentieth century, the government's drainage policy, historian Geoff Park observes, was underpinned by four main ideas: first, that wetlands in their existing state were unproductive wastelands that were only valuable because of their potential to be developed into fertile farmlands; second, wetlands did not hold any scenic value and should not be preserved (unlike certain remnants of Indigenous forests, birds, lakes, and mountains); third, that legally wetlands were future parcels of land (Park 2001). This assumption (of wetlands as potential land) meant that Māori entitlements to wetlands (authority over and rights to access and use resources) were considered by both the courts and the government to transfer with land titles (once wetlands were "unwatered"). Fourthly, the transformation of wetlands into farmlands was declared of national significance that it necessitated both governments (central and local governments) and individuals to intervene and fund it to ensure that the process was a success (Parsons and Nalau 2016; Parsons 2019). These four tenets negatively impacted Māori who's ancestral and livelihoods ties were bound to the Waipā wetland ecosystems, and for whom the existing wetlands were of immense 
value (socially, culturally, spiritually, and economically) in their watered (undrained) state.

The drainage schemes were essentially cooperative development ventures between the settler state and individuals, which relied on common (European/Pākehā) understandings of how land and water should be used. An essential part of this was the denigration of wetlands, Māori waterscapes (created and maintained by hapū and iwi for generations), and the resources associated them. Drainage and the replacement of wetlands with productive grasslands were positioned as part of the process of creating a civilised society. Māori who lived within and around Waipā River catchment, even if they held land titles, were given limited opportunities to assert different values and understandings of wetlands.

Given wide-ranging powers, drainage boards could acquire private land (specifically targeting Māori land that was undrained), construct drainage works (even if local landowners opposed it), manage watercourses, and impose rates (taxes) on landholders (Parsons and Nalau 2016; Parsons 2019). The various drainage legislation specifically included provisions that targeted Māori land (including section 83 of Drainage Act 1904) and made Māori land eligible for local government rates (section 88(2) of Drainage Act 1904). Since the majority of land in Rohe Potāe was still Māori land in the early twentieth century, Māori landowners were liable for pay rates to whatever drainage board their landholdings were located in (which often included multiple boards). Māori encountered substantive difficulties paying their rates (with few banks willing to give Māori mortgages on their properties or access any other financial assistance), and many were forced to lease or sell their parcels of land out of financial necessity; that is, to ensure they and their whānau were kept feed, clothed, and with a roof over their heads. Also, many took work as manual labourers tasked with clearing forests, draining wetlands, constructing roads, and cultivating lands on behalf of settlers. The operations of the Kawa Drainage Board, which we will briefly discuss, demonstrate the diversity of ways Māori sought to maintain their ties to their whenua and awa, and the different tactics individuals chose to engage with settler colonialism. 


\section{Te Kawa Wetlands and the Operations of the Kawa Drainage Board}

Te Kawa wetlands (see Fig. 4.14: Map of Railway Line), an area of approximately 6000 acres located between Otorohanga and Te Awamutu, was a major food gathering site (mahinga kai) for local hapū to harvest tuna (freshwater eels) as well as other aquatic biota (Unknown Author 1907b). While at the start of the twentieth century local Māori retained ownership of the area surrounding Kakepuku and Te Kawa wetlands, by 1907 the majority of the 6000 acres was either owned or leased to Pākehā. Media and government reports were filled with descriptions of how Te Kawa wetlands "ha[d] for generations existed as an unprofitable waste", but with Pākehā occupation and proposed drainage works it was "being turned to its legitimate use" Unknown Author 1907a). A local newspaper even wrote a piece that celebrated the success of Pākehā in securing "the necessary signatures" of Māori landholders to gain the leaseholds and proclaimed that actions to drain the wetlands and convert it all to pastures much occur as soon as possible (Unknown Author 1907b). Settlers and politicians, quoted in local media, repeatedly emphasised that the removal of wetlands was vital to their collective goal: the creation of profitable dairy farms. Both explicitly and implicitly, in public and private accounts, the 'settlers' or 'pioneers' (as they described themselves) of the Waipā discussed their beliefs about what was the correct way to live, work, and interact with the land and water, biological and biophysical components of the freshwater system. Māori ways of living, cultivating, and harvesting resources from their whenua, awa (Waipā River), and repo, from the Western/Pākehā worldview, were deemed inappropriate, 'wasteful', and unproductive as the focus was not directed at intensive agriculture and the accumulation of goods by individuals in a way that closely replicated those of Pākehā. Yet, amongst Māori, there was not necessarily a universal agreement about how to engage with settler colonialism, and the newly dominant Western/Pākehā worldview, economic arrangements, legal system, institutions, and ways of interacting with environments. 
The "opening up" of the Rohe

Potae and the railway:

Ngāti Maniapoto and other

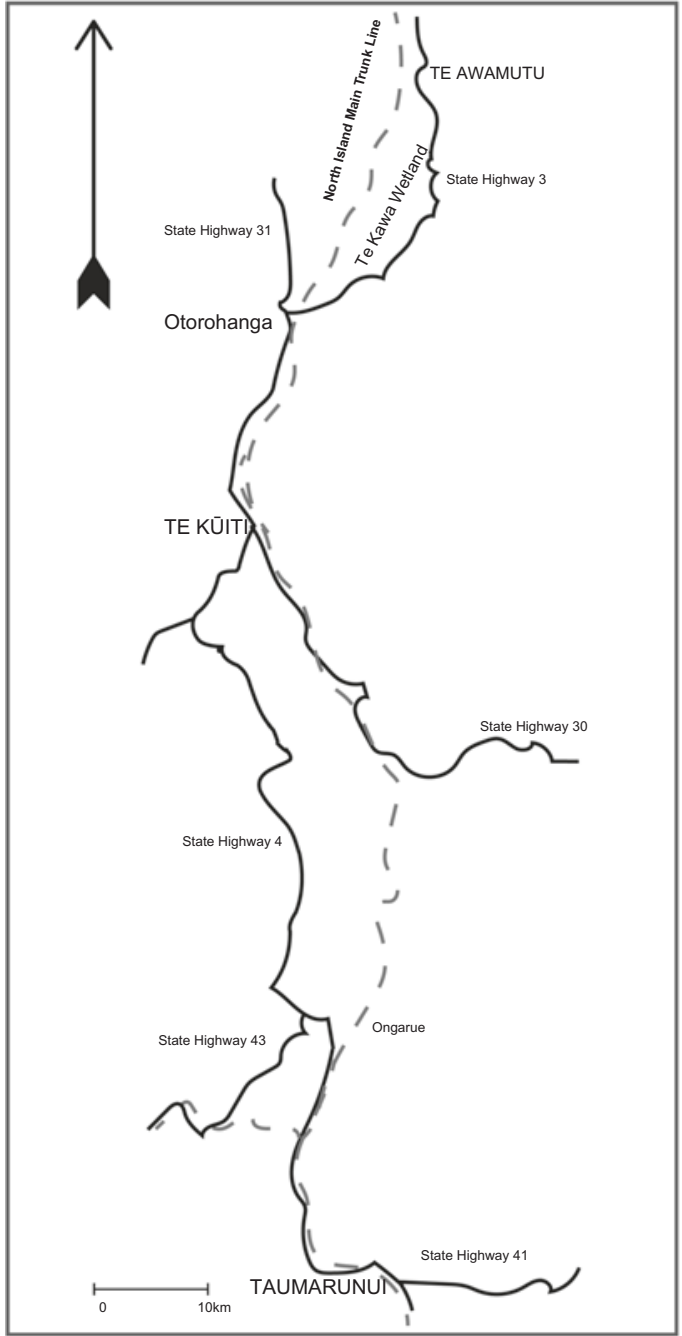

members of Kīngtanga rejected initial government proposals to

allow the construction of a

railway through Rohe Pōtae.

Ngāti Maniapoto were deter-

mined to retain their rangati-

ratanga over the area.The question of the railway line prompted

conflict amongst Kingitanga

supporters, with the Crown

initially seeking to negotiate

directly with King Tawhaio rather

than with Ngāti Maniapoto

leadership. After sustained

negotiations between govern-

ment officials, Kīngitanga leaders,

and Ngāti Maniapoto chiefs

between 1882 and 1885, Ngāti

Maniapoto chiefs agreed to allow

the survey of Te Rohe Potae and

the construction of the railway

line through their rohe on the

proviso that the government

agreed to certain conditions. In

return for allowing the railway

through Rohe Potae the govern-

ment made numerous promises

to iwi. This included: giving a

legal amnesty on Maori 'rebels';

the right of the Kingitanga to

continue to govern their own

affairs; the prohibiton of liquor

from Ngati Maniapoto territory;

the provision of a parlimentary

seat to a Ngāti Maniapoto cheif

(Wahanui); providing schools and

hospitals to Māori communities;

and that Māori within Rohe Pōtae

to continue to exercise exclusive

responsibility for the manage-

ment of their own lands and

waters. While the government did

honour its promise to grant the

amnesty, other promises were

not honoured. Most notably the

government ignored its guaran-

tees to Ngāti Manaipoto to

protect their lands and waters,

and did not allow Ngāti Maniapo-

to to continue to exercise their

rangatiratanga and kaitiakitanga

over its rohe.

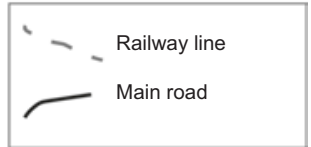

Fig. 4.14 Map showing the central section of the railway line that was constructed through Rohe Pōtae (King Country) following negotiations between Ngāti Maniapoto and the Crown. For a more detailed discussion about Ngāti Maniapoto's decision to allow the railway to be constructed through their territory see recent publications by Michael Belgrave and the Waitangi Tribunal (Belgrave 2017; Waitangi Tribunal 2018) 
On 30 July 1908, the Kawa Drainage Scheme was proclaimed by New Zealand's Governor-General, and elections were held for the first board members in September 1908 (Unknown Author 1908). It was highly unlikely that the majority of Māori with ties to Kawa were consulted; we found no evidence within the government archives or newspaper reports for this time period that indicate any official hui to discuss the drainage scheme or works was held with Ngāti Maniapoto. However, John Ormsby was appointed as the returning officer for the election of the Drainage Board and later was its Clerk, and did seek to ensure that Ngāti Maniapoto interests were represented to a limited degree; such as advocating that Māori should be permitted access to bank loans to allow them to develop their lands into dairy farms. Indeed, Ormsby was firmly in support of the 'development' of Te Rohe Pōtae so long as Māori were able to receive the same economic benefits as Pākehā. At a meeting in December 1907 to discuss the proposed drainage of Te Kawa wetlands, for instance, Ormsby declared that settlers, government officials, and local Māori were all in universal agreement that draining the wetlands would be beneficial "not only to those [people] present but to the district as a whole" (Unknown Author 1907c).

In the late nineteenth and early twentieth century, Ormsby was an important figure for Ngāti Maniapoto, following on from earlier leaders including Wahanui Huatare and Rewi Maniapoto, and played a key role negotiating with the Crown and its agencies about Pākehā settlement of Rohe Pōtae (Ministry of Culture and Heritage 2018; A. Ormsby 1907; A. S. Ormsby 1920; Unknown Author 1927). Born in 1854 at Pirongia, John Ormsby was the fourth child of an Irish schoolmaster, Robert Ormsby and his wife Mere Pianika (Mary Bianca) Rangihurihia. From a young age, he was mentored by senior rangatira (most notably Wahanui Huatare) and given leadership opportunities designed to ensure he could act as an intermediary between Te Ao Māori (the Māori world) and Te Ao Pākehā (the Pākehā world) on behalf of Ngāti Maniapoto. In 1883, for instance, Ormsby was appointed to lead the Kawhia Native Committee (the institutional precursor of the local council) and later sought to ensure Māori were given more seats within the committee to try to temper Pākehā settler priorities. Most significantly, in 1884 Ormsby and other successfully petitioned the New Zealand Parliament to allow Wahanui 
Huatare to address the House of Representatives on issues relating to Ngāti Maniapoto's lands and the proposed railway line. Wahanui and Ormsby travelled to Wellington and spoke to politicians about Ngāti Maniapoto's commitment to retaining their rangatiratanga over their lands and their willingness to negotiate with the government. The visit bore fruit for Ngāti Maniapoto in that the Native Minister Balance agreed to meet with and form an agreement with representatives of iwi in 1885 (discussed earlier) in which the Crown promised Māori control over their lands, forests and resources, protection from negative effects, and material benefits from the railway (which was subsequently ignored by the settler government as was earlier with Te Tiriti guarantees). Ormsby was later involved in a variety of different administrative and business roles, including as an assessor on behalf of the Native Land Court, the owner of farming ventures, a hotel, butchery, stables, land insurance and bakery; he helped establish the township of Otorohanga and was the chair of the Otorohanga Town Board (Ministry of Culture and Heritage 2018). He even established the first branch of the New Zealand Farmers' Union (which today is known as Federated Farmers) in Rohe Pōtae. He, therefore, came to situate himself in the middle ground or hybrid space between Te Ao Māori and Te Ao Pākehā or Ngāti Maniapoto and settlercolonial worlds. In doing so, Ormsby was able to access financial loans (which most Māori struggled to do at the time), amassed a large portfolio of profitable businesses (in which he employed his Māori relatives), gained political influence (at least at a local government level), and promoted Māori economic development so long as it conformed to the prevailing (Pākehā settler-colonial) capitalist modes of accumulation. He positioned himself as a moderniser who sought to ensure that Ngāti Maniapoto interests were maintained while ensuring that Pākehā settlement and economic development was encouraged. He encouraged Māori to engage in economic activities and employed many of his whānau within his businesses. Ormsby, who straddled multiple worlds-Te Ao Māori and Te Ao Pākehā-like many other Māori leaders in Aotearoa at the time (including Apirana Ngata from the East Coast iwi Ngāti Porou) emphasised the critical need for Māori to embrace Pākehā land development schemes (AJHR 1927; A. Ormsby 1907; A. S. Ormsby 1911). However, Ormsby's views about land, wetland drainage, and economic 
development stood at odds with other Māori in the area (including his Ngāti Maniapoto kin). The clash in differing ways of engaging with $\mathrm{Te}$ Ao Pākehā, maintaining mana (power, prestige, authority), and practising kaitiakitanga was highlighted in disputes surrounding the activities of the Kawa Drainage Board.

Three land parcels under the domain of the Kawa Drainage Board were specifically designated as 'eel reserves' due to the large numbers of pā tuna (eel weirs) that were used by hapū to harvest tuna (freshwater eels) (see Fig. 4.15). The practice of establishing certain eel reserves-Kakepuku 8A (Eel pa) 0.69ha, Kakepuku 8B (Eel pa) 1.38ha, Kakepuku 8C (Eel pa) $2.78 \mathrm{ha}$ _-was only, however, ever intended as a temporary measure by the drainage board to appease Māori (who continued to own the majority of land in the region and were only leasing it to Pākehā) (Kawa Drainage Board Clerk 1909). Indeed, pā tuna were of limited value

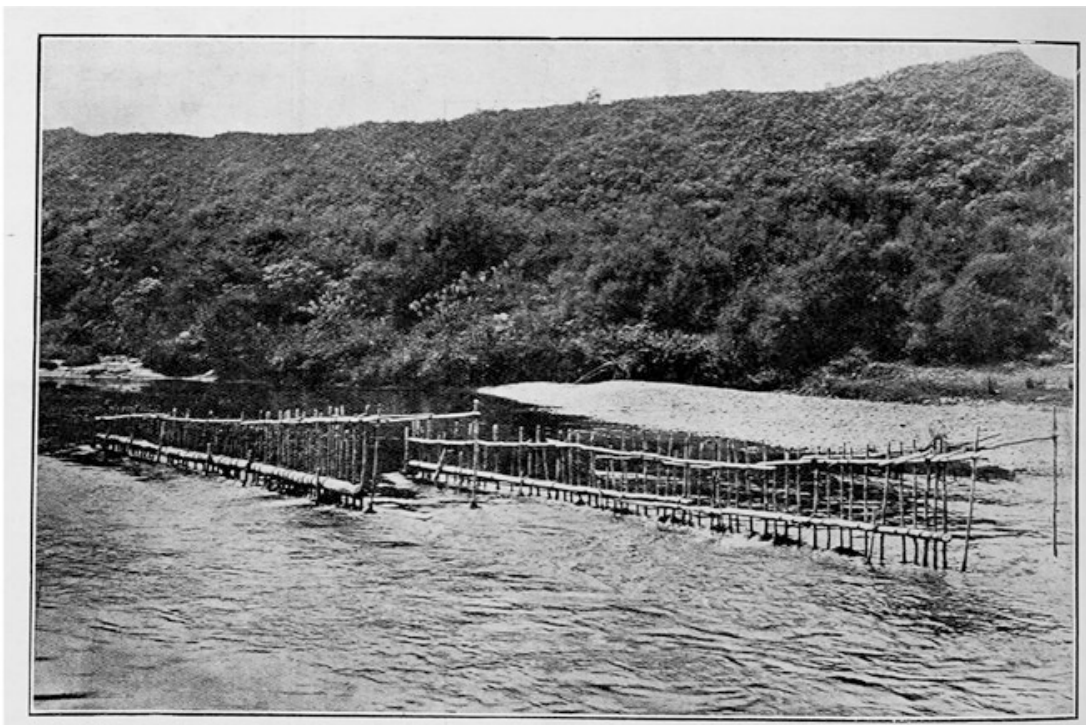

THE MAORI METHOD OF EEL-CATCHING: A WEIR CONSTRUOTED BY NATVES ON THE ONGARUE RIVER, AUCKLAND.

Fig. 4.15 Pā tuna (eel weir) in Ongarue River (located south of the Wāipa River) in 1908. Most pā tuna were comprised of two fences (pā tauremu) that funnelled the tuna (eels) into a hīnaki (eel pot). (Source: Auckland Libraries Heritage Collections AWNS-19080227-16-3) 
without the waters that supported tuna, and proposed drainage works threatened to destroy wetlands as mahinga kai for iwi. In response to this threat (to their food harvesting practices, relationships with their repo, and responsibilities as kaitiaki) twelve Māori wrote a letter to the Minister of Native Affairs in 1908 in which they outlined their concerns about the Kawa Drainage Board's proposed works to drain Te Kawa wetlands. They noted that they were not kept informed about the nature of the work, given the opportunity to provide feedback to the board about proposed decisions, or offered any financial compensation for the damage that drainage would cause to their capacities to harvest tuna. In addition, the leaseholder (a Pākehā settler by the name of Walsh) had announced that he planned to implement the drainage works himself, with the support the Kawa Drainage Board, and there was nothing that the Māori owners of the land could do to prevent him. Accordingly, Te Koro and his fellow owners requested that the Minister of Native Affairs:

protect us in this matter lest our rights [are] wrenched from us by the Pakeha [sic] breaking down and doing away with our eel-weirs without paying compensation. We want, first of all a proper agreement as to payment to us, because the loss of the eel-weirs would deprive us of the support which we gain therefrom, a source of food year after year; and indeed our main source of food supply when the blight destroys our crops. (Te Koro 1908)

Ngawareo Te Koro and the eleven other signatories cited the articles of Te Tiriti o Waitangi that assured Māori continued rangatiratanga over their taonga (including their fisheries) and the Crown's protection of their rights to their resources. They requested that the Minister of Native Affairs intervene to halt the drainage works until an amicable agreement could be reached between the two parties, and also sought financial compensation for the damage to their pā tuna $(£ 2000)$.

The Under-Secretary of the Native Department requested that government officials based within Rohe Pōtae investigate the matter and provide a report back to the Minister. The Pākehā Judge (connected to the NLC) who inquired into the issue (unsurprisingly) agreed with Kawa Drainage Board's decisions. He declared that wetlands of Te Kawa were 
"lying unproductive and in its present state is absolutely no value to its Native owners" (President of the Maniapoto-Tuwharetoa District Maori Land Board 1909). Despite its lack of value, the Judge declared, its Māori owners "refused to lease or sell" their lands "except at an exorbitant price". Therefore the Kawa Drainage Board was operating in everyone's best interest. The Kawa Drainage Board was formed by:

all the persons whose properties will be benefited from the drainage of the swamp, and it appears to me that the Natives are alarmed, because they see, that instead of getting the outrageous price they asked, there is a chance that they will be paid only what is a fair share of the weir. (President of the Maniapoto-Tuwharetoa District Maori Land Board 1909)

After this incredibly limited inquiry, the Minister of Native Affairs essentially washed his hands of the matter and declared it an issue for the courts rather than the government. He informed Te Koro et al. that their only option was to seek legal representation and lodge legal proceedings against Kawa Drainage Board to prevent the drainage works (Fisher 1909). From an iwi Māori perspective, the central government (the Crown) was (as per the Treaty of Waitangi and the 1885 railway agreement) required to protect Māori land and other taonga from damage. So Te Koro and other Māori owners requested that the Crown (and its agency the Native Affairs Department) intervene to stop the drainage works. However, like elsewhere in Aotearoa, the Crown refused to intervene to protect Māori interests and declared that wetland drainage was critical to the progress and development of society; and that the only remedy available to Māori was through the courts.

Later that same year (in November 1909), the Māori owners of the 'eel reserve' Kakepuku 8C (some of whom were signatories to the letter to the Native Minister) were notified by the Kawa Drainage Board that it would construct a drainage canal through their land (Kawa Drainage Board Clerk 1909). The nine owners of Kakepuku 8C vehemently opposed the action as they argued it would destroy their pā tuna and their capacities to harvest tuna. They once again sought to negotiate with the board. They approached local members of parliament for support (which was in keeping with Māori governance protocols that centred on face-to-face 
meetings and decisions based on the ongoing dialogue between parties until agreements could be reached). However, due to the Minister of Native Affair's refusal to assist Hone Te Anga and his fellow landowners of Kakepuku 8C, they were forced to seek legal representation from a Pākehā legal firm (Bamford \& Brown) to help them negotiate with the Kawa Drainage Board. They continued to hope that negotiations with the board (which included Ngāti Maniapoto's John Ormsby) would ensure that they could prevent or at least mitigate the damage caused by drainage works to their pā tuna (Bamford and Brown 1909). Solicitors Bamford \& Brown wrote and met with members of the drainage board and outlined their clients' objections to the planned engineering works on their land. On the basis that the said "piece of land [was] an eel pa" that they held "for their benefit and for the benefit of the Ngatingawaero [sic] tribe" (Ngāti Ngāwaero is a hapū of Ngāti Maniapoto), and it was of "great value ... and importance to them" (Bamford and Brown 1909). The proposed drainage canal would, they argued, "destroy the character of the said piece of land as an eel pa", and the owners could not "be adequately compensated for such destruction". Indeed, no loss of money would be sufficient to compensate for the lack of eels. The drainage works, the solicitors warned the drainage board, was both "inequitable" and would "infringe the just legal equitable rights of the objectors to maintain the said piece of land as an eel pa" (Bamford and Brown 1909). The two parties (Bamford \& Brown and the Kawa Drainage Board) could not reach an out of court agreement, and in May 1910 the New Zealand Supreme Court heard the case. The Court sided with the Kawa Drainage Board and declared that the Māori landowners could be financially compensated for the loss of the eel weirs. The rights of Māori, the Judge argued, "should not be allowed to stand in the way of draining a large area of the country" (Bamford 1910; Unknown Author 1910).

After the Supreme Court rejected their legal objection of the drainage works, the plaintiffs (Hone Te Anga et al.) then sought to address the issue of compensation, which was allowed under the Land Drainage Act 1908. In May 1910, Harry Bamford, solicitor of the plaintiffs, submitted that since the drainage operations would "put an end to or substantially put an end to the supply of eels in the stream through the said land and will seriously affect the riparian rights of the plaintiffs" they required a 
large sum—£1500 — in compensation (Bamford 1910). To give some sense of how much $£ 1500$ was in Aotearoa in May 1910, the figure (according to the New Zealand Reserve Bank inflation calculator) is the equivalent of $\$ 260,327.59$ New Zealand Dollars (NZD) in December 2019. The Kawa Drainage Board's solicitor (George Kent) declared the amount of money plaintiffs wanted was completely out of the question. Indeed, Kent argued, that the plaintiffs should only receive a far smaller figure because they would receive "certain advantages" from the drainage works, including an increase in their property values and the potential that drains may "increase the number of eels" in the waterways. Moreover, he added that "eel pas were of a diminishing character and that on the admission of the Plaintiffs the younger natives of the district do not take the same interest in the said eel pas as did their predecessors and that a time would come when the said rights would practically be neglected" (Kent 1910).

The Court adjourned the case in August 1910, with the two parties meant to negotiate an agreement. However, this did not happen, and the Kawa Drainage Board proceeded with its planned drainage works. Māori landowners unsuccessfully sought a legal injunction against the works. By April 1914, when the Supreme Court heard the case again, the board had finished the majority of engineering works, with the Mangawhero Stream that flowed through the block of land diverted, and eel weirs removed (Unknown 1914a). The Supreme Court's decision once again reflective European understandings of the environment, wetlands, and resource usage. The "Kawa Swamp", Judge Cooper stated, "was noted for the very large number of edible eels which it contained ... flourished exceedingly" and was used "for the common benefit of all Natives living in the district, and were a very material part of their general food supply". The drainage scheme was, however, "now in a very advanced state", with the Mangawhero Stream dredged and straightened, and the wetlands partially drained. As a consequence of the drainage works, the number of eels was "materially diminished", with "the facility of catching eels by means of weirs greatly restricted". On completion of the drainage scheme, the entire area, the Judge stated, would cease to be wetlands that were only useful as a "fattening place for eels" and instead be "the most valuable dairy-farm land" (Te Anga 1914). 
As the legal case continued through the court system, the solicitors and their Māori clients (Hone Te Anga and his kin) employed Western/ Pākehā modernist legal framings of ownership and private property rights in support of their arguments about their freshwater, land, and resource rights. The adoption of modernist framing was an essential part of Māori efforts to receive financial compensation for the loss of wetlands and the decreased (or destroyed) capacities to harvest tuna and other freshwater biota used for food, medicine, art, and cultural activities. However, the legal case was reported in national and local newspapers as a story:

of the clash of the modern with the ancient; of the dislocation that must almost inevitably occur when the advance of civilisation overtakes the lagging customs of the aboriginal. A local authority had drained a swamp; the success of the drainage works necessarily interfered with the fattening grounds of the eels; the Maoris whose food supply was then interfered with sought compensation. (Unknown 1914b)

The Supreme Court determined that the Māori owners were entitled to compensation, but it was restricted to the damage to their pa tuna but not the reduction in the number of tuna in the stream. The Drainage Board, the Supreme Court declared, possessed exclusive authority to alter waterways and drain wetlands. Thus the rights of Māori (and financial claims) were highly constrained. The Supreme Court referred the issue of compensation to the Compensation Court, which ultimately awarded the landowners $£ 150$ in compensation (far less than the $£ 1500$ sought by plaintiffs and most of the money likely went to paying the legal costs) (Unknown 1914a; Unknown Author 1914).

Rather than a clash of civilisations, the case of Te Kawa wetlands demonstrates that Māori sought to retain their rangatiratanga and practice kaitiakitanga through political and legal forums. In their different engagements with drainage board operations and the courts, Māori discussed, debated and challenged commonly-held attitudes, values and relationships; sometimes articulating Te Ao Māori holism and communalism, and other times embracing $\mathrm{Te}$ Ao Pākehā individualism and 
forward-thinking time (M. Jackson 1993; O’Regan 1984; Ruru 2009; Salmond 2017; Tipa et al. 2016).

The Te Kawa wetlands case study highlights those different ways in which Māori (as individuals and members of whānau, hapū, and iwi) sought to challenge the dominant settler-colonial assumptions about wetlands as unhealthy, unproductive and unused spaces. In doing so, Māori articulated relational connections with their whenua, awa, repo, and other dimensions of their waterscapes that extended beyond Western liberal ontologies centred on binary divisions between nature/culture and land/water. They as members of whānau, hapū, iwi, linked through whakapapa (genealogy) to each other as well as their rohe and all those beings (including plants, animals, and supernatural) that lived within it, continued to advocate for the importance of activities that were not part of the market economy or those of Te Ao Pākehā. From this perspective, while land, rivers, wetlands and biota were fundamental to Māori subsistence activities, they were never capable of being reduced to merely exploitable resources. Instead, there were always social, ethical and spiritual dimensions that bound Māori as tangata whenua (which translates directly as people of the land) to their landscapes and waterscapes. Yet, not all Māori articulated these views and instead advocated for Māori to adopt Te Ao Pākehā (at least where it concerned economic development activities). Thus, individuals like John Ormsby and many of his descendants operated as intermediaries between Te Ao Māori and Te Ao Pākehā and took efforts to retain tribal lands as the Crown endeavoured to acquire more and more Māori land. Yet, at the same time, the rules of the game were those defined and implemented by the settler-colonial state and which privileged Western liberal worldviews and land use at the extent of modes of life, ways of knowing and being.

The example of Te Kawa wetlands illustrates that Western conceptualisations of what constitutes environmental justice (and injustice) do not adequately address Māori, other Indigenous and non-Western, relational ways of thinking about human-environment relationships. In 1908 and 1909, the plaintiffs (Hone Te Anga et al.), like many other Māori at the time as well as prior and subsequent, sought to articulate to non-Māori their ways of conceiving and experiencing their worlds, which rests in a system of reciprocal relationships with their whenua, awa, biota and the 
metaphysical beings that dwelled within them. Through their legal case, Māori emphasised how the loss of access to important mahinga kai was not something that could be simply replaced with other types of food, as those foods held social, cultural, and spiritual dimensions, which connected tangata whenua to their ancestors (human-ancestors, godancestors, and other more-than-human-ancestors). These different ways of seeing and living (underpinned by different ontologies and epistemologies) were illustrated in how Māori and Pākehā understood the Te Tiriti o Waitangi/the Treaty of Waitangi, as well as later conflicts over governance and resource management. These differences between Māori and Pākehā ways of seeing and interacting with their environments (their modes of life), we suggest. The failures of the Crown (the settler colonial state) and the settler dominated legal system to recognise Māori values, knowledge, and modes of life (including their ways of governing and managing whenua and awa) as valid ways of thinking and being in the world were one critical form of environmental injustice experienced by Māori.

When we take into account how Māori and Pākehā represented and interacted with wetlands, it raises important questions about how scholars define environmental justice and injustices. At the same time, most environmental justice theorising and activism focus on present-day examples of environmental (in)justice as opposed to historical studies, environment injustices rarely (if ever) pop into existence overnight. Indeed, societies, communities, and human-environmental relationships do not exist in a historic vacuum. Instead, the social and environmental injustices and a plethora of environmental crises and challenges we face at the start of the twenty-first century are a product of past decisions, policies, and practices over the years, decades, and centuries across multiple scales. In Aotearoa, we argue that Māori experiences of environmental injustices are inextricably bound up with the historical and continuing processes and practices of settler colonialism. Yet, traditional accounts of environmental justice do not adequately take into account Māori values, interests, knowledge, and their experiences of environmental injustices.

If we examine wetlands through a distributive environmental justice lens (which seeks to identify the distribution of environmental "goods" and "harms" across society and/or space) then environmental injustice 
was not evident (Arcury and Quandt 2009; Brook 1998; Bullard 1993; Hockman and Morris 1998; Hofrichter 2002; Lee 2002; Pastor et al. 2001). From this perspective, a wetland drainage scheme that provided (supposedly) equal distribution of "benefits" (as was argued by government officials about Te Kawa) would not be an example of environmental injustice (as equal benefits and harms were distributed across groups). However, as we outlined in Chap. 2, such a narrow framing of environmental justice ignores the social, cultural, and institutional contexts in which environmental injustices take place and the systematic acts of discrimination against marginalised populations that all play substantial roles in creating and sustaining environmental injustices. A distributive environmental justice lens, therefore, misses an important opportunity to critique the roles of capitalism and colonialism across multiple intersecting temporal and spatial scales (see Swyngedouw and Heynen 2003). All of which is particularly pertinent when thinking about the specific environmental injustices faced by Indigenous peoples, and how settlercolonialism manifested itself as social and eco-violence against Indigenous bodies and spaces (Hendlin 2019; S. Jackson 2018; Whyte 2014, 2016).

Recent work by decolonial scholars rejects environmental justice as distributive equity for being underpinned by Western ontologies that position 'nature' as something capable of being classified, objectified, exploited (Álvarez and Coolsaet 2018). Nature as something quantifiable and therefore distributable- be it as environmental goods (such as clean water, land, fisheries) or harms (such as air pollution or hazardous waste) — however, stands at odds with Māori and many other Indigenous peoples' ways of seeing the world. From such a reading of environmental justice as distributive, Māori within the Waipā catchment did not necessarily experience any environmental injustice as a consequence of their wetlands being drained. Any losses or damage that Māori communities suffered as a consequence (including diminished access to traditional food sources) could, as both Native Minister Balance and Judge Kent informed members of Ngāti Maniapoto iwi in 1885 and 1909 respectively, be simply replaced by other goods. For instance, tuna supplanted by cows. Indeed, anything of value, from the worldview of Pākehā, could be quantified and calculated into a monetary figure, and (if damaged) then financial compensation could be paid (even if it was only $£ 150$ in 
the case of pā tuna). However, even when Māori adopted the lexicon of settler colonialism (of modernity, capitalism, and individual property rights) in their complaints and legal cases about the damage of drainage works, their arguments were challenged and rejected by Pākehā on the basis that the things Māori valued (wetlands, tuna, pā tuna) were of minimal or no financial worth. The refusal of Pākehā (be it settlers, local government and central government officials, and representatives of the judiciary) to acknowledge Māori interests and their rights to maintain their ways of life, natural resource management regimes, and food and water cultures, was later rearticulated in debates about flood controls (discussed in the next chapter) and accusations that Māori received economic benefits from using "white man's utilities" (roads, bridges, urban water supplies, drainage works, and flood controls) without paying their local taxes (Álvarez and Coolsaet 2018). Indeed, as Walker (2009) has argued scholars need to look beyond where environmental harms and goods were and are located to consider the diversity of environmental risks and the multiple types of environmental injustices experienced by different communities in different ways, which work at different scales (Walker 2009, p. 615). He defines three conceptualisations of environmental justice in pluralistic terms; distributive (distribution of goods and bads); procedural (policies and processes including the equitable capacities to participate in decision-making); and recognition (of different knowledges, values, and peoples). In the Waipā freshwater system, the cumulative impacts of inequitable government policies and practices that marginalised Māori voices and modes of life, and the failure to acknowledge (misrecognition) of Māori values, laws and knowledge, and entire waterscapes were fundamental to the settler state-sponsored wetland drainage project which caused multiple environmental injustices for Māori. One major injustice related to the loss of pā tuna and tuna. Since tuna served (and still does serve) as socio-culturally important for riverine Māori for multiple reasons; tuna was a commonly harvested food source (that provided whānau/hapū with a healthy source of protein), given as a gift to demonstrate one's hospitality to guests (tuna was served at feasts and given to visitors as part of manaakitanga (showing hospitality, generosity and support for others), and was considered as kin to local hāpu (through whakapapa connections). Another injustice related to the 
separation of people from their whenua, awa, and repo with the establishment of drainage canals, construction of flood levees, and pollution of the waterways (which we discuss in the next chapter); these acts of ecological dispossession meant that tangata whenua were not able to access the products (food, water, and medicinal) that established socio-cultural, spiritual and economic connections.

The work of Indigenous scholar Coulthard (2014) similarly highlights how the historical and contemporary struggles of the Dene people, who comprise First Nations groups living in the Western Subarctic area of Canada, were not just against settler colonialism, but also capitalism. Dene communities, which includes Yellowknives, Sathu, Salvey, Tlicho and Chipewyan, not only challenge the distribution of environmental risks and impacts of dispossession but also demand the rights to live "in relation to one another and the natural world in non-dominating ways and nonexploitative terms" (Coulthard 2014, p. 13). Likewise, Escobar argues that present-day Colombian Indigenous and Afro-Colombian social movements are waged in the name of different ways of life (Escobar 2015, 2016). Such movements (both historical and contemporary) amongst Indigenous and marginalised non-Indigenous non-European communities in colonial and post-colonial societies conceptualise humanenvironmental relationships in non-binary terms and situate development in terms of reciprocal relations between ecological and human communities. The environmental injustices experienced by Māori were (and still are) grounded not only in economic, ecological systems, but also socio-cultural structures that marginalise Māori ways of knowing, knowledge, values, and ways of interacting with different worlds. Thus, acts of dispossession (which included drainage works) deprived Māori communities not only of their material modes of subsistence but also negatively impacted their physical and spiritual health (hauora) and wellbeing (encapsulated in the principles of mauri and wairua). Dispossession and colonial structures of power and control (which were diverse and permeated all society) involved the (mis)recognition of Indigenous values, identities and modes of life, and if ever acknowledged were simply ascribed Western ideas of development, economic values, and land ownership rights. 


\section{Conclusion}

Settler colonialism was (and still is) a system of socio-cultural, political, and economic domination that involves violent disruptions to Indigenous peoples' relationships with their waterscapes and landscapes. In the context of Aotearoa, settler colonialism manifested itself through a series of social, political, and ecological interventions that sought to dominate and radically remake the rohe (traditional territories) of Māori iwi (tribe) and hapū (sub-tribe). Like in other settler societies, settlers in Aotearoa (sometimes incidentally, other times deliberately) sought to establish their own homes, farms, factories, communities, institutions, and the entire settlercolonial state through the marginalisation and erasure of Indigenous places, which involved ecological remodelling. In this chapter, then, we explored just one element of settler-colonial domination: the transformations of wetlands into grasslands. In doing so, we are forced to exclude a wealth of other interrelated histories but direct readers attention to the work of scholars who explore colonial challenges to Māori sovereignty, health and wellbeing, language and education (Boast 2008; Anderson et al. 2014; Keenan 2014; Lange 1999; Mahuika 2019; Salesa 2001; Wanhalla 2006). However, we recognise that settler-colonial domination consists of insidious loops and sedimentation that seriously disrupted (but did not destroy) all elements of Indigenous cultural continuance, which encompasses social, cultural, ecological, spiritual, political and economic domains (Whyte 2018; Whyte et al. 2019).

We must think about how wetlands (loss, health, restoration) figure into how we think about healthy rivers and how we (Indigenous and non-Indigenous) respond to the challenges of the Anthropocene (Hatvany 2008; Parsons and Nalau 2016; Romero Lankao 2010; Vileisis 1999). The past and continuing efforts to remake the wetlands of Aotearoa is the manifestation of settler colonialism, which is enacted elsewhere using a variety of mechanisms but all aim to achieve the same end. Settlercolonial projects are directed at the appropriation of lands, waters, minerals, and other resources as well as the jurisdiction of Indigenous peoples not only to exploit natural resources and for establishing settlements, but also to facilitate the territorial foundation of dominant (hegemonic) neoEuropean societies (Bacon 2019; Belich 2009; Hiller 2017; Parsons and Nalau 2016; Meg Parsons 2019). 


\section{References}

AJHR. (1875). H-22 Boards of Health in the Various Provinces. Appendices of the Journal of the House of Representatives. Wellington: Government Printer.

AJHR. (1885a). G-02a Reports from Native Medical Officers. Appendix to the Journals of the House of Representatives, 1 January 1885. Appendices to the Journals of the House of Representatives. Wellington: Government Printer.

AJHR. (1885b). G-2. Notes of a meeting between Hon. Mr. Ballance and the Natives at the Public Hall at Kihikihi, on 4th February, 1885. Appendices of the Journal of the House of Representatives. Wellington: New Zealand Parliament. AJHR. (1911). C-11 Drainage Operations in the Rangitaiki Plains Report for the Year Ending 31 March 1911 (AJHR No. C-11). Appendices of the Journal of the House of Representatives. Wellington: Government Printer. Retrieved May 5, 2019, from http://paperspast.natlib.govt.nz/parliamentary/AJHR1911I.2.2.3.26.

AJHR. (1913). C-9 Drainage Operations in Hauraki Plains: Report for the Year Ended 31st March 1913. Appendices of the Journal of the House of Representatives. Wellington: New Zealand Parliament. Retrieved May 5, 2019, from http://paperspast.natlib.govt.nz/parliamentary/AJHR1913I.2.3.2.18.

AJHR. (1927). I-03 NATIVE AFFAIRS COMMITTEE (REPORTS OF THE). NGA RIPOATA A TE KOMITI MO NGA MEA MAORI. (Hon. Sir APIRANA NGATA, Chairman.), Untitled, 1 January 1927 (Appendices to the House of Reprsentatives No. I-03). Wellington: Government Printer. Retrieved May 5, 2019, from http://paperspast.natlib.govt.nz/parliamentary/AJHR1927-I.2.3.3.3.

Álvarez, L., \& Coolsaet, B. (2018). Decolonizing Environmental Justice Studies:

A Latin American Perspective. Capitalism Nature Socialism, 1-20.

Anderson, A., Binney, J., \& Harris, A. (2014). Tangata Whenua: An Illustrated History. Wellington: Bridget Williams Books.

Arcury, T. A., \& Quandt, S. A. (2009). Latinx Farmworkers in the Eastern United States: Health, Safety and Justice. Cham: Springer Science \& Business Media. Ausseil, A.-G. E., Jamali, H., Clarkson, B. R., \& Golubiewski, N. E. (2015). Soil Carbon Stocks in Wetlands of New Zealand and Impact of Land Conversion since European Settlement. Wetlands Ecology and Management, 23(5), 947-961.

Azarnivand, A., Chitsaz, N., \& Malekian, A. (2017). Designing a Risk-based Multi Criteria Framework for River Health Assessment: A Case Study of 
Taleghan Basin, Iran. International Journal of Hydrology Science and Technology, 7(1), 63-76.

Bacon, J. M. (2019). Settler Colonialism as Eco-Social Structure and the Production of Colonial Ecological Violence. Environmental Sociology, 5(1), 59-69.

Bamford, H. D. (1910). Sworn Statement of Harry Dean Bamford, 13 May 1910, Para 5. BCDG A1492 Box 1, A16. Archives New Zealand: Auckland.

Bamford \& Brown. (1909). Letter: Bamford \& Brown to Kawa Drainage Board Clerk, 4 December 1909, BCDG A1492 Box 1, A16. Auckland: Archives New Zealand.

Barugil, J. J. (1883, August 2). Mr J. J. Barugil on the Waikato. Waikato Times, p. 3.

Beattie, J. J. (2005). Environmental Anxiety in New Zealand, 1850-1920: Settlers, Climate, Conservation, Health, Environment. (Thesis). University of Otago. Retrieved May 31, 2020, from http://ourarchive.otago.ac.nz/ handle/10523/347.

Beattie, J. (2008). Colonial Geographies of Settlement: Vegetation, Towns, Disease and Well-being in Aotearoa/New Zealand, 1830s-1930s. Environmental History, 14(4), 583-610.

Belgrave, M. (2017). Dancing with the King: The Rise and Fall of the King Country, 1864-1885. Auckland: Auckland University Press.

Belich, J. (2009). Replenishing the Earth: The Settler Revolution and the Rise of the Angloworld. Oxford: Oxford University Press.

Boast, R. (2008). Buying the Land, Selling the Land: Governments and Māori Land in the North Island 1865-1921. Wellington: Victoria University Press. Retrieved April 21, 2017, from https://books.google.co.nz/books?hl=en\&lr= \&id=VpUSvrc7snkC\&oi=fnd\&pg=PR11\&dq=related:rMTvJd8z9nQJ:sch olar.google.com/\&ots=66dD0cl-A3\&sig=Vl0zRTAyBx2qm98QtTUL_ Ak7ZLY.

Bradford, L. E., Bharadwaj, L. A., Okpalauwaekwe, U., \& Waldner, C. L. (2016). Drinking Water Quality in Indigenous Communities in Canada and Health Outcomes: A Scoping Review. International Journal of Circumpolar Health, $75(1), 32336$.

Brealey, K. G. (1995). Mapping Them 'Out': Euro-Canadian Cartography and the Appropriation of the Nuxalk and Ts'ilhqot'in First Nations' Territories, 1793-1916. The Canadian Geographer / Le Géographe canadien, 39(2), 140-156. Brook, D. (1998). Environmental Genocide. American Journal of Economics and Sociology, 57(1), 105-113. https://doi.org/10.1111/j.1536-7150.1998. tb03260.x. 
Bullard, R. D. (1993). Race and Environmental Justice in the United States. Yale Journal of International Law, 18, 319.

Byrnes, G. (2001). Boundary Markers: Land Surveying and the Colonisation of New Zealand. Wellington: Bridget Williams Books. Retrieved April 21, 2017 , from https://books.google.co.nz/books?hl=en\&lr=\&id=be6IHXxBhZEC\&o $\mathrm{i}=$ fnd \&pg = P P $1 \& \mathrm{dq}=$ related:rMTvJd 8z9nQJ:scholar.google. com/\&ots=VWgbTl7cCv\&sig=-BgBay-40Kg59vp3MaPRMRX06pg.

Cameron, E. (2011). Copper Stories: Imaginative Geographies and Material Orderings of the Central Canadian Arctic. Rethinking the Great White North: Race, Nature and the Historical Geographies of Whiteness in Canada, 169-190. Carlson, A. (2010). Drain the Swamps for Health and Home: Wetlands Drainage, Land Conservation, and National Water Policy, 1850-1917 (PhD Thesis). University of Oklahoma, Oklahoma.

Chetty, S., \& Pillay, L. (2019). Assessing the Influence of Human Activities on River Health: A Case for Two South African Rivers with Differing Pollutant Sources. Environmental Monitoring and Assessment, 191(3), 168.

Chiang, C. Y. (2008). The Nose Knows: The Sense of Smell in American History. The Journal of American History, 95(2), 405-416.

Clarkson, B. R., Ausseil, A.-G. E., Gerbeaux, P., et al. (2013). Wetland Ecosystem Services. In Ecosystem Services in New Zealand: Conditions and Trends (pp. 192-202). Lincoln: Manaaki Whenua Press.

Coulthard, G. S. (2014). Red Skin, White Masks: Rejecting the Colonial Politics of Recognition. Minneapolis: University of Minnesota Press. Retrieved May 19, 2019, from https://muse.jhu.edu/book/35470.

Cowan, J. (1928). The Romance of the Rail: A Descriptive and Historical Story of the North Island Main Trunk Railway. The New Zealand Railways Magazine, 3(3). Retrieved May 26, 2018, from http://nzetc.victoria.ac.nz/ tm/scholarly/tei-Gov03_03Rail-t1-body-d16-d6.html.

Cumberland, K. B. (1941). A Century's Change: Natural to Cultural Vegetation in New Zealand. Geographical Review, 31(4), 529-554.

Davidson, N. C. (2014). How Much Wetland has the World Lost? Long-Term and Recent Trends in Global Wetland Area. Marine and Freshwater Research, 65(10), 934-941.

Dench, S. (2011). Invading the Waikato: A Postcolonial Re-view. New Zealand Journal of History, 45(1), 33-49.

Dench, S. J. (2018). Imaging and Imagining the Waikato: A Spatial History c.1800-c.1914 (Thesis). The University of Waikato, Hamilton. Retrieved May 4, 2019, from https://researchcommons.waikato.ac.nz/handle/10289/ 11856. 
Denyer, K., \& Robertson, H. (2016). Wetlands of New Zealand. In C. M. Finlayson, G. R. Milton, R. C. Prentice, \& N. C. Davidson (Eds.), The Wetland Book (pp. 1-15). Springer.

Durette, M., Nesus, C., Nesus, G., \& Barcham, M. (2009). Māori Perspectives on Water Allocation. Wellington: Ministry for the Environment.

Edmundson, A. (2019). 'Preserving the Papuan': JHP Murray and Doomed Race Theory in Papua New Guinea. History and Anthropology, O(0), 1-20.

Ellinghaus, K. (2006). Indigenous Assimilation and Absorption in the United States and Australia. Pacific Historical Review, 75(4), 563-585.

Escobar, A. (2015). Degrowth, Postdevelopment, and Transitions: A Preliminary Conversation. Sustainability Science, 10(3), 451-462.

Escobar, A. (2016). Thinking-Feeling with the Earth: Territorial Struggles and the Ontological Dimension of the Epistemologies of the South. AIBR, Revista de Antropología Iberoamericana, 11(1), 11-32.

Fisher, M. (1909). Handwritten Note Fisher to Grace, 14 January 1909, Te Kawa Swamp, Protest against Drainage (Effects of Eel Weirs), MA1 973. Wellington: National Archives.

Flikke, R. (2016). South African Eucalypts: Health, Trees, and Atmospheres in the Colonial Contact Zone. Geoforum, 76, 20-27.

Flint, N., Rolfe, J., Jones, C. E., Sellens, C., Johnston, N. D., \& Ukkola, L. (2017). An Ecosystem Health Index for a Large and Variable River Basin: Methodology, Challenges and Continuous Improvement in Queensland's Fitzroy Basin. Ecological Indicators, 73, 626-636.

Grey, G. (1849). Letter: Sir George Grey to Daniel Bolton. 3 March 1849. GLNZ G1.B6a. Grey New Zealand Letters. Auckland: Auckland Libraries.

Guthrie-Smith, H. (1969). Tutira: The Story of a New Zealand Sheep Station (4th ed.). Wellington: AH\& AWReed.

Halliday, S. (2001). Death and Miasma in Victorian London: An Obstinate Belief. BMJ [British Medical Journal], 323(7327), 1469-1471.

Hamilton, R. B. (1968). Military Vision and Economic Reality: The Failure of the Military Settlement Scheme in the Waikato, 1863-1880.

Hammer, G. E. J. (1991). A Pioneer Missionary: Raglan to Mokau 1844-1880: Cort Henry Schnackenberg. Auckland: Wesley Historical Society (New Zealand).

Hanrahan, M. (2003). Water Rights and Wrongs: Safe Drinking Water Remains a Distant Hope for Residents of Black Tickle and Many Other Indigenous People in Canada. Alternatives Journal, 29(1), 31-35.

Hargreaves, R. P. (1959). The Maori Agriculture of the Auckland Province in the Mid-nineteenth Century. The Journal of the Polynesian Society, 68(2), 61-79. 
Hargreaves, R. P. (1961). Maori Flour Mills of the Auckland Province: 1846-1860. The Journal of the Polynesian Society, 227-232.

Hatvany, M. (2008). Environmental Failure, Success and Sustainable Development: The Hauraki Plains Wetlands through Four Generations of New Zealanders. Environmental History, 14(4), 469-495.

Hemming, S., Rigney, D., Muller, S., Rigney, G., \& Campbell, I. (2017). A New Direction for Water Management? Indigenous Nation Building as a Strategy for River Health. Ecology and Society, 22(2).

Henderson, J., Germann, P., Macky, M., Finch, J., \& Fentress, J. (1994). Paterangi Remembers. Hamilton: Federated Farmers of New Zealand. Retrieved January 23, 2018, from https://natlib.govt.nz/records/31194692. Hendlin, Y. H. (2019). Environmental Justice as a (Potentially) Hegemonic Concept: A Historical Look at Competing Interests between the MST and Indigenous People in Brazil. Local Environment, 24(2), 113-128.

Hiller, C. (2017). Tracing the Spirals of Unsettlement: Euro-Canadian Narratives of Coming to Grips with Indigenous Sovereignty, Title, and Rights. Settler Colonial Studies, 7(4), 415-440.

Hockman, E. M., \& Morris, C. M. (1998). Progress towards Environmental Justice: A Five-year Perspective of Toxicity, Race and Poverty in Michigan, 1990-1995 1. Journal of Environmental Planning and Management, 41(2), 157-176.

Hofrichter, R. (2002). Toxic Struggles: The Theory and Practice of Environmental Justice. University of Utah Press.

Howe, K. R. (1970). Missionaries, Maoris, and "Civilization" in the UpperWaikato, 1833-1863: A Study in Culture Contact: With Special Reference to the Attitudes and Activities of the Reverend John Morgan of Otawhao (Thesis). University of Auckland. Retrieved May 31, 2020, from https://catalogue. library.auckland.ac.nz/permalink/f/gkavgk/uoa_alma21159775720002091.

Hursthouse, C. F. (1861). New Zealand: The "Britain of the South". London: E. Stanford.

Jackson, M. (1993). Land Loss and the Treaty of Waitangi. Te Ao Märama: Regaining Aotearoa. Mäori Writers Speak Out, 2.

Jackson, S. (2018). Indigenous Peoples and Water Justice in a Globalizing World. The Oxford Handbook of Water Politics and Policy, 120.

Johnstone, B. M., \& Roberts, P. R. (2004). Not a Pioneer!: A Memoir of Waipa and Raglan, 1871-1960: Memories of Bernice Monrath Johnstone of Three Oaks, Whatawhata, New Zealand. Ottawa: P.R. Roberts. Jones, V. (1996, May 9). Shirley Finlayson. Retrieved September 20, 2018. 
Kansal, M. L. (2018). Issues and Challenges of River Health Assessment in India. In Water Resources Management (pp. 105-119). Springer.

Kawa Drainage Board Clerk. (1909). Kawa Drainage Board Clerk to the Owners of Kakepuku 8C, 13 November 1909, BCDG A1492 Box 1, A16. Auckland: Archives New Zealand.

Keenan, E. (2014). Māori Urban Migrations and Identities, 'Ko Ngā Iwi Nuku Whenua': A Study of Urbanisation in the Wellington Region during the Twentieth Century. Retrieved March 19, 2020, from http://researcharchive. vuw.ac.nz/handle/10063/3576.

Kelm, M. E. (2005). Diagnosing the Discursive Indian: Medicine, Gender, and the "Dying Race". Ethnohistory, 52(2), 371-406.

Kent, G. S. (1910). Sworn Statement of George Sedgwick Kent, 24 June 1910, para 6, BCDG A1492 Box 1, A16. Auckland: Archives New Zealand.

Kerry-Nicholls, J. H. (1884). The King Country: Or, Explorations in New Zealand. A Narrative of 600 Miles of Travel through Maoriland. London: S. Low, Marston, Searle \& Rivington.

Kiechle, M. A. (2017). Smell Detectives: An Olfactory History of NineteenthCentury Urban America. Seattle: University of Washington Press.

Lange, R. (1999). May the People Live: A History of Maori Health Development 1900-1920. Auckland University Press.

Lee, C. (2002). Environmental Justice: Building a Unified Vision of Health and the Environment. Environmental Health Perspectives, 110(Suppl 2), 141-144.

Levy, E. B. (1970). Grasslands of New Zealand. Wellington: Government Printer. Mahuika, N. (2019). Rethinking Oral History and Tradition: An Indigenous Perspective. Oxford: Oxford University Press.

McGovern, F. E. (1986, February 18). A Hard Life: Reminisces 1902-1919. Interview with Mrs Flo (Florence) McGovern of Peachgrove Road Hamilton by Jeff Downs. Retrieved October 1, 2018.

McGregor, R. (1997). Imagined Destinies: Aboriginal Australians and the Doomed Race Theory, 1880-1939. Carlton, VIC: Melbourne University Press.

McLellan, J. M. (2017). Soldiers and Colonists (Master of Arts). Victoria University of Wellington, Wellington.

Meyer, M. (1996). Interview with Mary Meyer by Vicki Jones in 1996. Retrieved October 1, 2018.

Ministry of Culture and Heritage. (2018). Ormsby, John. Dictionary of New Zealand Biography-Te Ara. Retrieved January 24, 2018 https://teara.govt. nz/en/biographies/2o8/ormsby-john/print.

Mitsch, W. J., \& Gosselink, J. G. (2000). The Value of Wetlands: Importance of Scale and Landscape Setting. Ecological Economics, 35(1), 25-33. 
Morgan, J. (1849). Letter: Rev. John Morgan to Sir Geogre Grey. 31 December 1849. GLNZ M44.2. Grey New Zealand Letters. Auckland Libraries, Auckland.

Morgan, J. (1862). Letter: Rev. John Morgan to Sir George Grey. 11 August 1862. GLNZ M44.23. Grey New Zealand Letters. Auckland Libraries, Auckland.

Morgan, J. (1864). Reverend John Morgan to Browne, 29 December 1864, Gore Browne 1/2d, Archives New Zealand, Wellington.

Morris, J. D. K., \& Ruru, J. (2010). Giving Voice to Rivers: Legal Personality as a Vehicle for Recognising Indigenous Peoples' Relationships to Water? Australian Indigenous Law Review, 14(2), 49-62.

New Zealand Parliament. (1858). Waste Lands Act 1858 (21 and 22 Victoriae 1858 No 75). Retrieved March 12, 2020, from http://www.nzlii.org/nz/ legis/hist_act/wla185821a22v1858n75265/.

New Zealand Parliament. (1875). Napier Swamp Nuisance Act. Retrieved February 12, 2018, from http://www.nzlii.org/nz/legis/hist_act/ nsna187539v1875n4343/.

New Zealand Parliament. (1881). Drainage Act. Retrieved April 9, 2020, from http://nzlii.org/nz/legis/hist_act/da188145v1881n27149/.

New Zealand Parliament. (1893). Land Drainage Act. Retrieved September 9, 2018, from http://www.nzlii.org/nz/legis/hist_act/lda189357v1893n46176/. New Zealand Parliament. (1904). Land Drainage Act. http://www.nzlii.org/nz/ legis/hist_act/lda19044ev1904n13192/.

New Zealand Parliament. (1908a). Hauraki Plains Act. Retrieved April 9, 2020, from http://www.nzlii.org/nz/legis/hist_act/hpa19088ev1908n21279/.

New Zealand Parliament. (1908b). Land Drainage Act. http://www.legislation. govt.nz/act/public/1908/0096/latest/whole.html.

New Zealand Parliament. (1910). Rangitaiki Lands Drainage Act.

New Zealand Parliament. (1924). Reserves and other Lands Disposal and Public Bodies Empowering Act. Retrieved January 24, 2018, from http://legislation.govt.nz/act/public/1924/0055/latest/DLM198760.html.

O'Donnell, E., \& Macpherson, E. (2019). Voice, Power and Legitimacy: The Role of the Legal Person in River Management in New Zealand, Chile and Australia. Australasian Journal of Water Resources, 23(1), 35-44.

O'Regan, S. (1984). Māori Perceptions of Water in the Environment: An Overview. Waiora, Waimaori, Waikino, Waimate, Waitai: Maori Perceptions of Water and Environment.

Ormsby, A. (1907). Government Dealings with Maori Lands: From a Maori Point of View. 1907. King Country Chronicle. 
Ormsby, A. S. (1911). Natives and Rates. King Country Chronicle, 9 September. Te Kuiti.

Ormsby, A. S. (1920). Taxing Native Lands. Waipa Post, 7 September, p. 6. Te Awamutu.

Park, G. (2001). Effective exclusion. An Exploratory Overview of the Crown's Actions and Maori Responses Concerning Flora and Fauna, 1912-1983. Report Prepared for the Waitangi Tribunal. Wellington: Legislation Direct.

Park, G. (2002). Swamps which might Doubtless Easily be Drained: Swamp Drainage and Its Impact on the Indigenous (Environmental Histories of New Zealand) (pp. 176-185). Melbourne: Oxford University Press.

Parsons, M. (2019). Environmental Uncertainty and Muddy Blue Spaces: Health, History and Wetland Geographies of Aotearoa New Zealand. In R. Foley, R. Kearns, T. Kistemann, \& B. Wheeler (Eds.), Blue Space, Health and Wellbeing: Hydrophilia Unbounded (pp. 205-227). London: Routledge.

Parsons, M., \& Nalau, J. (2016). Historical Analogies as Tools in Understanding Transformation. Global Environmental Change, 38, 82-96.

Pastor, M., Sadd, J., \& Hipp, J. (2001). Which Came First? Toxic Facilities, Minority Move-In, and Environmental Justice. Journal of Urban Affairs, 23(1), 1-21.

Patrick, R. J. (2011). Uneven Access to Safe Drinking Water for First Nations in Canada: Connecting Health and Place through Source Water Protection. Health \& Place, 17(1), 386-389.

Phillips, C., Johns, D., \& Allen, H. (2002). Why did Maori Bury Artefacts in the Wetlands of Pre-contact Aotearoa/New Zealand? Journal of Wetland Archaeology, 2(1), 39-60.

Poelina, A., Taylor, K. S., \& Perdrisat, I. (2019). Martuwarra Fitzroy River Council: an Indigenous Cultural Approach to Collaborative Water Governance. Australasian Journal of Environmental Management, 26(3), 236-254.

President of the Maniapoto-Tuwharetoa District Maori Land Board. (1909). President of the Maniapoto-Tuwharetoa District Maori Land Board to the Under Secretary of the Native Affairs Department, 11 January 1909, Te Kawa Swamp, Protest against Drainage (effects of eel weirs), MA1 973, Archives New Zealand, Wellington. Unpublished.

Romero Lankao, P. (2010). Water in Mexico City: What Will Climate Change Bring to Its History of Water-Related Hazards and Vulnerabilities? Environment and Urbanization, 22(1), 157-178.

Ruru, J. (2009). Property Rights and Maori: A Right to Own a River? In New Zealand Centre for Environmental Law Conference. 
Said, E. W. (1978). Orientalism (1st ed.). London: Pantheon Books.

Salesa, T. D. (2001). "The Power of the Physician": Doctors and the 'Dying Maori' in Early Colonial New Zealand. Health and History, 3(1), 13-40.

Salmond, A. (2017). Tears of Rangi: Experiments Across Worlds. Auckland University Press.

Savage, A. G. F. (1847). Chapter 1: Journey into the Interior of New ZealandThe Waikato. In Life and Scenes in Australia and New Zealand. London: Smith, Elder, and Co. Retrieved July 18, 2018, from http://www.enzb.auckland.ac.nz/document/?wid=610\&page $=0 \&$ action $=$ searchresult $\&$ target.

Simmonds, J. C. (1938). Letter from: J.C. Simmonds, Engineer, Mangapu Drainage Board, to T. Wightman Otorohanga. 15 December 1938. Folder: Rivers and Drainage-Waipa River. 1935-1953. Container Code: C 58395. Archives Reference Number: BAAS A269 5113 Box 62. Item Reference: C. Record Number: 96/434220. Archives New Zealand, Auckland. Unpublished.

St. John, J. H. A. (1873). Pakeha Rambles through Maori Lands. Wellington: Robert Burrett. Retrieved November 27, 2018, from http://www.enzb.auckland.ac.nz/document/?wid=1471\&page $=0 \&$ action $=$ null.

Swyngedouw, E., \& Heynen, N. C. (2003). Urban Political Ecology, Justice and the Politics of Scale. Antipode, 35(5), 898-918. https://doi.org/10.1111/ j.1467-8330.2003.00364.x.

Te Anga, H. Hone Te Anga v Kawa Drainage Board-(1914) 33 NZLR 1139 (High Court 1914). Retrieved January 7, 2018, from http://www.lawreports. nz/hone-te-anga-v-kawa-drainage-board-1914-33-nzlr-1139/.

Te Koro, N. (1908). Letter from Ngawere Te Koro and others to Thomas Fisher, 23 October 1908, Te Kawa Swamp, Protest against Drainage (Effects of Eel Weirs), MA1 973, Archives New Zealand, Wellington. Unpublished.

Thomson, J. T. (1867). Rambles with a Philosopher or, Views at the Antipodes by an Otagonian. Dunedin: Mills, Dick and Company.

Tipa, G., Nelson, K., Home, M., \& Tipa, M. (2016). Policy Responses to the Identification by Maori of Flows Necessary to Maintain their Cultural Values. In 37th Hydrology \& Water Resources Symposium 2016: Water, Infrastructure and the Environment (p. 552). Engineers Australia.

Tua Tua Moana Swamp. (1915a, May 25). Waikato Times, p. 6.

Tua Tua Moana Swamp. (1915b, May 26). New Zealand Herald, p. 8.

Unknown. (1876, April 1). The Health of the District. Waikato Times, p. 2.

Unknown. (1914a, June 6). Eel Swamp or Dairy Farm. Waikato Times, p. 2.

Unknown. (1914b, April 24). A Migration of Eels. Waikato Argus, p. 2. 
Unknown Author. (1846, March 14). Progress in Native Civilization. New Zealander. New Zealander, p. 3.

Unknown Author. (1854, February 25). Native Flour Mills. Maori Messenger: Te Karere Maori, p. 1.

Unknown Author. (1859, December 24). Notes of a Visit to the Thames and Waikato Districts. New Zealander, p. 5.

Unknown Author. (1862, July 7). Upper Waipa. From Our Own Correspondent. July 2nd, 1862. Daily Southern Cross, p. 3.

Unknown Author. (1863, September 5). Travels in Walkato.-Continued. Taranaki Herald, p. 2.

Unknown Author. (1864a, January 27). First Military Settlement in Waikato. Lake Wakatipu Mail, p. 3.

Unknown Author. (1864b, March 1). Military Settlers. New Zealander, p. 5.

Unknown Author. (1864c, May 12). Military Settlement of the North Island. Nelson Examiner and New Zealand Chronicle, p. 7.

Unknown Author. (1865a, February 28). The State and Prospects of the Waikato Settlements. New Zealander, p. 3.

Unknown Author. (1865b, March 24). Waikato Military Settlement. 24 March 1865. Daily Southern Cross, p. 4.

Unknown Author. (1865c, June 7). Lecture on the Waikato by Mr. Whyman. 7 June 1865. Daily Southern Cross, p. 4.

Unknown Author. (1867, May 29). Recollections of a Waikato Missionary. Daily Southern Cross, p. 5.

Unknown Author. (1873, February 22). Health in Perfumes. Press, p. 5.

Unknown Author. (1875, July 1). Health from Flowers. Daily Southern Cross, p. 1.

Unknown Author. (1876a, April 18). Tree Planting in Our Townships. Waikato Times, p. 3.

Unknown Author. (1876b, April 29). Planting Trees in the Waikato. Waikato Times, p. 2.

Unknown Author. (1878a). The Swamp Nuisance. Hawke's Bay Herald, p. 2.

Unknown Author. (1878b, May 9). The Journey to Alexandra. Auckland Star, p. 2.

Unknown Author. (1878c, May 9). The Soldier's Grave's. Auckland Star, p. 3.

Unknown Author. (1879, March 1). Tourist Notes on Hawke's Bay. New Zealand Country Journal, 3(2), 87.

Unknown Author. (1884). Cussin's Survey, Survey of the King Country. Evening Post. 
Unknown Author. (1885, March 28). Ladies' column. Hints for Housewives. Waikato Times, p. 2.

Unknown Author. (1887, August 19). Waikato Swamps and Swampers. Press, p. 6.

Unknown Author. (1907a, December 28). Kawa Drainage Scheme. King Country Chronicle, p. 2.

Unknown Author. (1907b, October 22). Mcfarlane's Swamp. Waikato Independent, p. 4.

Unknown Author. (1907c, December 13). Untitled. Kawhia Settler. Kawhia.

Unknown Author. (1908, 4 September). District Pars. King Country Chronicle, p. 2.

Unknown Author. (1909, September 30). Dismal Swamp. Waikato Independent, p. 4.

Unknown Author. (1910, May 11). Kawa Drainage Board. King Country Chronicle, p. 3.

Unknown Author. (1914, June 12). The Eel Pa Case. Waikato Argus, p. 2. Unknown Author. (1927). Obituary: John Ormsby. Waipa Post, p. 5.

Unknown Author. (1935, August 23). Waipa Drainage. New Zealand Herald, p. 13.

Unknown Author. (1970). Folder: Rivers and Drainage_Lower Waikato Waipa Control Scheme Raglan County-Rakaumanga Houses. 1970-1975. Archives Reference Number: BAPP 5113 Box 1674. Container Code: C 13 388. Record Number: 96/434000/0/105. Archives New Zealand, Auckland. Unpublished.

Vileisis, A. (1999). Discovering the Unknown Landscape: A History of America's Wetlands. Washington, DC: Island Press. Retrieved May 12, 2019, from https://books.google.co.nz/books?hl=en\&lr=\&id=gHRO32i6et0C\&oi=fnd \&pg=PR2\&dq=east+anglia+wetlands+history+drainage\&ots=X_A2_Hzqk $\mathrm{N} \& s i g=Z M t H 7 C O A y I L X i E Q b O k f t P i l O W$ po\#v=onepage\&q\&f=false. Von Hochstetter, F. (1867). New Zealand and its Physical Geography, Geology and Natural History with Special Reference to the Results of Government Expeditions in the Provinces of Auckland and Nelson. Stuttgart: J. G. Cotta. Retrieved July 18, 2018, from http://www.enzb.auckland.ac.nz/document/?wid=434\& action=null.

Waitangi Tribunal. (2018). Te Mana Whatu Ahuru: Report on Te Rohe Pōtae Claims Pre-Publication Version Parts I and II. Wellington: Unpublished. Walker, G. (2009). Beyond Distribution and Proximity: Exploring the Multiple Spatialities of Environmental Justice. Antipode, 41(4), 614-636. 
Wanhalla, A. (2006). Housing Un/healthy Bodies: Native Housing Surveys and Maori Health in New Zealand 1930-45. Health and History, 100-120. Westmacott, S. (1977). The After-breakfast Cigar. AH \& AW Reed.

Whyte, K. P. (2014). Indigenous Women, Climate Change Impacts, and Collective Action. Hypatia, 29(3), 599-616.

Whyte, K. P. (2016). Is it Colonial Déjà Vu? Indigenous Peoples and Climate Injustice. In Humanities for the Environment (pp. 102-119). London: Routledge.

Whyte, K. P. (2018). Settler Colonialism, Ecology, and Environmental Injustice. Environment and Society, 9(1), 125-144.

Whyte, K. P., Talley, L., \& Gibson, J. D. (2019). Indigenous mobility traditions, colonialism, and the anthropocene. Mobilities, 14(3), 319-335.

Wilkinson, G. T. (1892). G.T. Wilkinson, Otorohanga. 23 November 1892.

Subject: Forwarding letter from Wekerua Ngamuka re closing of track through Kakepuku No. [Number] 12 Block. R22400219, ACHI, 16036, 1892, MA 1863 1892-2099, National Archives, Wellington.

Wolfe, P. (2006). Settler Colonialism and the Elimination of the Native. Journal of Genocide Research, 8(4), 387-409.

Worboys, M. (1994). From Miasmas to Germs: Malaria 1850-1879. Parassitologia, 36(1-2), 61-68.

Open Access This chapter is licensed under the terms of the Creative Commons Attribution 4.0 International License (http://creativecommons.org/licenses/ by/4.0/), which permits use, sharing, adaptation, distribution and reproduction in any medium or format, as long as you give appropriate credit to the original author(s) and the source, provide a link to the Creative Commons licence and indicate if changes were made.

The images or other third party material in this chapter are included in the chapter's Creative Commons licence, unless indicated otherwise in a credit line to the material. If material is not included in the chapter's Creative Commons licence and your intended use is not permitted by statutory regulation or exceeds the permitted use, you will need to obtain permission directly from the copyright holder.

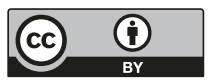

